
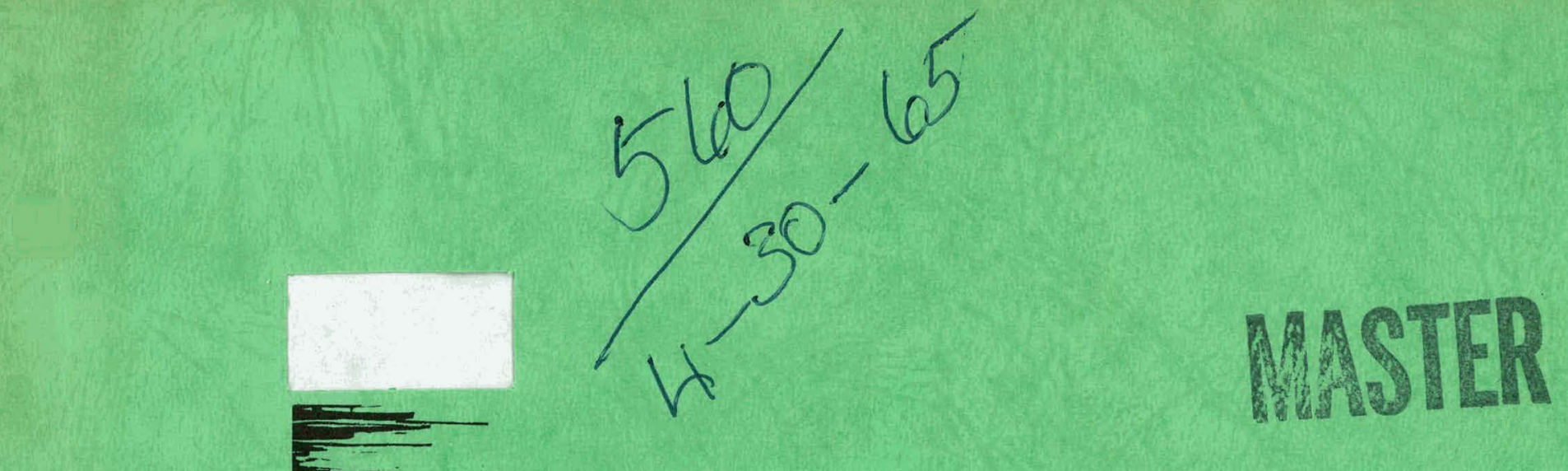

IOWA STATE UNIVERSITY

AMIES LADORATORY

\begin{tabular}{l}
\hline RESEARCH AND \\
\hline DEVELOPMENT \\
\hline REPORT \\
\hline
\end{tabular}

U.S.A.E.C.

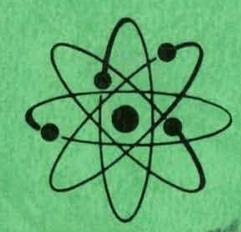

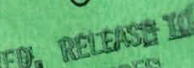

FATEMT GISARANGE OBTAMEDE. PROCEDURES

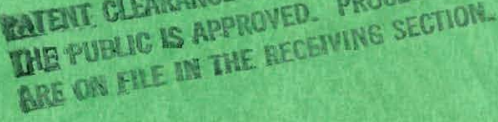




\section{DISCLAIMER}

This report was prepared as an account of work sponsored by an agency of the United States Government. Neither the United States Government nor any agency Thereof, nor any of their employees, makes any warranty, express or implied, or assumes any legal liability or responsibility for the accuracy, completeness, or usefulness of any information, apparatus, product, or process disclosed, or represents that its use would not infringe privately owned rights. Reference herein to any specific commercial product, process, or service by trade name, trademark, manufacturer, or otherwise does not necessarily constitute or imply its endorsement, recommendation, or favoring by the United States Government or any agency thereof. The views and opinions of authors expressed herein do not necessarily state or reflect those of the United States Government or any agency thereof. 


\section{DISCLAIMER}

Portions of this document may be illegible in electronic image products. Images are produced from the best available original document. 
IS -1122

Chemistry (UC-4)

TID-4500, February 1, 1965

\section{UNITED STATES ATOMIC ENERGY COMMISSION}

Research and Development Report

STABILITY CONSTANTS OF THE TRIVALENT LANTHANONS WITH SOME

ALPHA-HYDROXYCARBOXYLIC

$\alpha \quad$ ACIDS

by

George S. Paul and Jack E. Powell

February, 1965

\section{Ames Laboratory at}

Iowa State University of Science and Technology

F. H. Spedding, Director

Contract W-7405 eng -82 
This report is distributed according to the category Chemistry (UC-4) as listed in TID-4500, February 1, 1965.

\section{LEGAL NOTICE}

This report was prepared as an account of Government sponsored work. Neither the United States, nor the Commission, nor any person acting on behalf of the Commission:

A. Makes any warranty or representation, expressed or implied, with respect to the accuracy, completeness, or usefulness of the information contained in this report, or that the use of any information, apparatus, method, or process disclosed in this report may not infringe privately owned rights; or

B. Assumes any liabilities with respect to the use of, or for damages resulting from the use of any information, apparatus, method, or process disclosed in this report.

As used in the above, "person acting on behalf of the Commission" includes any employee or contractor of the Commission, or employee of such contractor, to the extent that such employee or contractor of the Commission, or employee of such contractor prepares, disseminates, or provides access to, any information pursuant to his employment or contract with the Commission, or his employment with such contractor.

Printed in USA: Price $\$ 3.00$. Available from the Clearinghouse for Federal Scientific and"T echnical Information, National

Bureau of Standards, U. S. Department of

Commerce, Springfield, Virginia 
ABSTRACT

I. INTRODUCTION . 1

II. CALCULATION OF STABILITY CONSTANTS 10

III. EXPERIMENTAL PROCEDURE AND RESULTS · 21

$\begin{array}{ll}\text { IV. DISCUSSION } & 30\end{array}$

V. SUMMARY . 56

$\begin{array}{ll}\text { VI. BIBLIOGRAPHY } & 57\end{array}$

VII. APPENDIX A: EXPERIMENTAL DATA FOR DETERMINATION OF IONIZATION CONSTANTS OF THE LIGAND ACIDS 63

VIII. APPENDIX B: EXPERIMENTAL DATA FOR THE RAREEARTH ISOPROPY LGLYCOLATES

IX. APPENDIX C: EXPERIMENTAL DATA FOR THE RARE-EARTH METHYLISOPROPYLGLYCOLATES 69

X. APPENDIX D: EXPERIMENTAL DATA FOR THE RARE-EARTH TERTIARYBUTYLGLYCOLATES

XI. APPENDIX E: EXPERIMENTAL DATA FOR THE RARE- 
$\because z \therefore$

3

$\because \cdots$

IS -1122

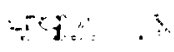
i. 
IS - 1122

\title{
STABILITY CONSTANTS OF THE TRIVALENT LANTHANONS WITH SOME ALPHA-HYDROXYCARBOXYLIC ACIDS
}

George S: Paul and Jack E. Powell

\begin{abstract}
The first three stepwise formation constants of the 2-hydroxy-3methylbutanoate (isopropylglycolate), 2, 3-dimethyl-2-hydroxybutanoate (methylisopropylglycolate), 3,3-dimethyl-2-hydroxybutanoate (tertiarybutylglycolate), and 2-hydroxy-2, 3,3-trimethylbutanoate (methyltertiarybutylglycolate) complexes of the trivalent rare earths and yttrium were determined at $25^{\circ} \mathrm{C}$ and an ionic strength of 0.1 molar $\left(\mathrm{NaClO}_{4}\right)$. The stabilities of the complexes followed the ionic radius trend quite regularly. The stabilities generally decreased with increasing complexity of the alkyl substituents on the ligand, but replacing a hydrogen atom by a methyl group invariably enhanced the stabilities of the complexes, especially in the case of the heavier, smaller rare-earth ions. It was postulated that the stabilities of the heavier rare-earth complexes with the methyl-substituted homologues were enhanced because of a smaller, more favorable hydroxyl-carboxyl bond angle.
\end{abstract}




\section{INTRODUCTION}

The lanthanons or rare-earth elements, according to the most widely accepted use of the term, comprise the elements lanthanum through lutetium (atomic numbers 57-71) in which $144 \mathrm{f}$ electrons are being successively added to the lanthanum configuration. Since the chemistry of lanthanum is a prototype of this closely allied group of elements, it is generally included as one of the rare earths even though it possesses no $4 f$ electrons. Some chemists also prefer to include yttrium because of its similarity to the rare-earth elements, while others go even further and include scandium because of its close relationship to yttrium. This author included yttrium in his investigations because of its close resemblance to the rare earths proper and its ready availability. Scandium was not included due to its scarcity and the fact that its much smaller radius imparts to it some properties which are distinctly dif'ferent from the other members of the group. Promethium occurs in nature only in vanishingly small quantities since all of its isotopes are radioactive, and hence it was not considered in this work. The claim of the Finnish chemist, Gadolin, in 1794, of the separation of the oxide of a new element from a swedish mineral was the actual beginning of rare-earth history, even though it was later accepted that the supposedly pure 
compound was actually a mixture of all the rare-earth oxides.

The use of the word "rare" in naming the rare earths was probably justified in the days of the early investigations of the group because of the scarcity of the known sources of the elements. Now there are about 150 different rare-earth minerals listed. As a group, the rare earths are more abundant than many of the more fampliar elements such as lead, tin, zine, mercury, dind guld. They are wldely distributed in naturc and usually occur with some of the less familiar elements such as niobium, tantalum, thorium, and zirconium. Elements of odd atomic number are less abundant than adjacent elements of even atomic number. Many minerals contain rare earths, but their chief importance lies in their other constituents. Important sources for the rare earths used in the Ames Laboratory are the phosphate mineral monazite which is roughly composed of $90 \%$ cerium group rare earths and 10\% yttrium group rare earths and thorium; xenotime, another rare-earth phosphate which is a good source of the heavier rare earths; and euxenite and gadolinite, both of which contain variable amounts of the light and heavy rare earths.

A constant demand for macro quantities of exceptionally pure samples of the rare earths has existed since the beginning of the Manhattan project. Europium, gadolinium, and samarium are of interest in nuclear applications because 
they have a high cross section for absorption of thermal neutrons, and thus have possibilities for use as control rods in reactors. On the other hand, yttrium has a low thermal neutron absorption cross section (1) and can thus be used as a container for nuclear reactions. Among nonnuclear uses of the rare earths are the use of neodymium and praeseodymium in glass which has the property of absorbing light in the region of the sodium $D$ line, thulfum in a portable $\mathrm{X}$-ray unit, mixed rare-earth oxides in carbon electrodes to produce high intensity light, alloyed with iron for lighter filints, certain europium chelates in lasers, and lanthanum oxide to give glass a higher refractive index permitting the use of thinner light lenses for reduction of chromatic aberration.

Prior to the advent of ion-exchange techniques, the laborious processes of selectlve precipitation and fractional crystallization afforded the best means of separating these elements. As would be expected from similarities in inner and outer shell atomic configurations, from aqueous electrode and gaseous ionization potentials, and from ionic and atomic sizes, all of the rare-earth elements form the same general types of compounds, and these compounds have very similar properties. The stabilities and solubilities of the various classes of compounds are nearly the same. The gradation in properties, however, of certain compounds 
in which the oxidation state of each rare earth is the characteristic +3 is of sufficient magnitude to permit separation, although the experimental procedures may be extremely tedious. One of the most successful separations by fractional crystallization employed the slightly soluble tris-mandelate complexes of rare-earth mixtures (2).

All previous methods of separation except for special cases (such as removal of europium by reduction to the divalent state and precipitation as $\mathrm{EuSO}_{4}$ (3) and removal of cerium in the tetravalent state (4)) have been replaced by ion-exchange resin separations developed during 1941-1946 and perfected for use on a large scale during the following decade. Although the chemistries of all the rare-earth elements in the +3 oxidation state are almost identical, there are small quantitative differences which vary systematically from lanthanum to lutetium with yttrium usually falling somewhere between samarium and holmium. The ionexchange method of separation is based on the fact that the steady decrease in size of the rare-earth ion and consequent decrease in basicity means that there should be a steady increase in the stability of the chelates formed by the rareearth ions as the atomic number of the rare earth increases. The first consequence of this is that the hydrated radii of the trivalent rare-earth ions increase with increasing atomic number; since the binding of cations to anionic sites 
of the exchange resin seems to involve electrostatic attraction of the hydrated cation by the negative site, it is found that the larger the hydrated radius of the cation, the less strongly is it bound. Thus this effect alone tends to give a separation of the trivalent rare earths when a solution containing several of them passes slowly through a column of cation-exchange resin, with the heavier members coming through first.

The separation obtainable because of differing preferences of the hydrated cations for the exchange resin can be significantly enhanced by employing complexing agents. Just as the smaller radius of the heavier of two rare-earth ions will cause it to have the larger hydrated radius, and hence smaller tendency to be held by the resir, its smaller radius will cause it to form stronger complexes, thus positively enhancing its preference for the aqueous phase.

The characteristics of a good eluant for ion-exchange work include: (a) Favorable separation factors, that is, relatively large differences in stability between chelates of adjacent rare earths. (b) Appreciable solubility of both the eluant itself and the rare-earth chelate. (c) Formation of a rare-earth chelate which is of the right magnitude of stability.

Very high stability of the chelate gives rise to a slow rate of exchange of the rare-earth ion between the resin and 
the aqueous phase and necessitates an excessively slow elution rate, whereas very low stability would not appreciably enhance the degree of separation achieved by preferential adsorption of the lighter rare earths by the resin.

The first eluant to be used on a large-scale basis for ion-exchange separation of the rare earths was a citric acidammonium citrate buffer $(5-10)$. Due to limited solubility and poor selectivity for some of the rare earths, it was soon displaced by other, more efficient eluants. An efficient method of ion-exchange separation now being used in the Ames Laboratory consists of separation of the lighter rare earths up to erbium using EDTA as the eluant and the heavier rare earths employing HEDTA (11-13). The selectivity of EDTA is very good for the rare earths up to erblun, whereas, that of HEDTA is poor, especially near the middle of the series. Still HEDTA has a better selectivity than EDTA for the heavy end of the series. Elaborate large-scale column tcchniquoc such as those used at the Ames Laboratory now permll the separation of kilogram quantities of the rare earths in a very pure state, which are commercially available.

Solective solvent sxtrnction of the trivalent rare earths is another of the new methods of separation which, however, has not yet attained the commercial importance of the lon-exchange method. Among the extraction techniques is the increased extractability with increasing atomic number 
of the trivalent rare earths from nitric acid solutions with tributyl phosphate in an inert solvent (14, 15). Various other organic phosphates, phosphoric acids, and acidic phosphonates have been investigated recently as potential extractants (16).

Numerous studies of the rare-earth alpha-hydroxycarboxylate systems have been made. Sonesson studied the glycolate systems at an ionic strength of 2.0 , and showed that the glycolate ligand is bidentate and apparently forms $1: 1,2: 1,3: 1$, and 4:1 complexes with the rare earths (17 19). Karraker studied the glycolate and also the lactate (methylglycolate, MG) systems at an ionic strength of 0.1 (20). He was able to determine only the first three successive formation constants since the low ionic strength limited the quantity of Iigand that he could add to his solutions. The alpha-hydroxyisobutyrate (dimethylglycolate, MMG) systems were studied by Kolat at an ionic strength of 0.1 (21), Deelstra et al. al an lonle strength of 0.2 (22), Stagg and Powell at an ionic strength of 0.5 (23), and Choppin and Chopoorian at an ionic strength of 2.0 (24). Choppin and Chopoorian also studied the glycolate and lactate systems at an ionic strength of $2.0(24)$. These studies have made stability constant data for these ligands available at several different ionic strengths. The stabilities of these complexes decrease in the order alpha-hydroxyisobutyrate 
$>$ lactate > glycolate.

Complete sets of stability constant data have also been obtained for the ethylglycolate ( $E G)$, methylethylglycolate (EMG), diethylglycolate (EEG) (25), and ethylisopropylglycolate (EIG) (26) species at an lonic strength of 0.1. Data for the methylethylglycolate and propylglycolate species of Ianthanum, cerium, dysprosium, and ytterbium, and for the methylpropylglycolate species of lanthanum, cerium, neodymium, samarium, dysprosium, and ytterbium have been obtained at an ionic strength of 1.0 (27). Also a complete set of data has been obtained for the 1-hydroxycyclopentane and 1-hydroxycyclohexane carboxylic acid species at an ionic strength of 0.1 (28).

The alpha-hydroxycarboxylate ligands have been examined for possible use as eluants in ion-exchange separations of the rare-earth elements $(29$ - 37). For example, lanthanum, cerium, praeseodymium, neodymium, promethium, and yllilum activities have been eluted with 0.25 molar lactate (33). The glycolate and lactate ligands were found to be relatively poor eluants because of a limited total range in selectivity and sulll changes in selectivity from one nloment to the next in the samarium - europium - gadolinium region. However, the alpha-hydroxyisobutyrate ligand approached EDTA in its ability to separate the rare-earth elements and their chemical analogs, the actinide elements (38). The 
alpha-hydroxycarboxylate chelates have not been used for the separation of rare eartis in macro quantities. They have, however, been used effectively for the separation of tracer quantities of the rare earths and the actinides.

This dissertation is concerned with the measurement of the formation constants of the trivalent rare-earth complexes of the isopropylglycolate (IG), methylisopropylglycolate (IMG), tertiarybutylglycolate ( $t-B G$ ), and methyltertiarybutylglycolate ( $t-B M G$ ) ligands and comparison of the results with previously determined constants of several other complexes of similar ligands. A complete investigation of the coordination behavior of the rare-earth ions would yield much basic information which would contribute a great deal to the understanding of these interesting elements. Such information would also have signiricant applications such as the possible development of even simpler and more economical methods for the separation of the individual rare-earth elements in a high state of purity. It is hoped that this work will be one more step toward elucidating the coordination behavior of the rare-earth ions and throwing more light on rare-earth chemistry. 


\section{CALCULATION OF STABILITY CONSTANTS}

One can represent the equilibria involved in a complex forming reaction between a metal $M$ and a ligand $A$ by the following series of stepwise reactions:

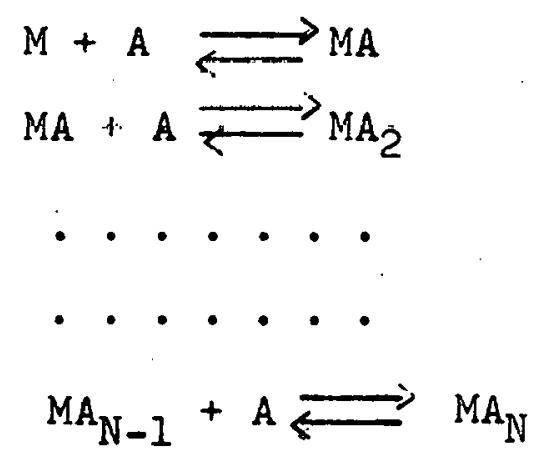

Since the number of water molecules in the coordination sphere of the metal is not generally determined experimental$1 \mathrm{y}$, this quantity was not included in the above equilibria. The charges of the various species were likewise not included since the complexation reactions involve no oxidation or reduction.

There also exists the possibllity for the formation of polynuclear complexes as represented by the equation $\mathrm{mM}+\mathrm{nA} \rightleftarrows \mathrm{M}_{\mathrm{m}} \mathrm{A}$. However, polynuclear complexes have been shown not to exist to any significant extent in stability constant determinations involving the acetate $(39,40)$, glycolate (19), isobutyrate, alpha-hydroxyisobutyrate, trihydroxyisobutyrate (41), methylethylglycolate, methylpropylglycolate, and propylglycolate (27), ligands and 
hence wlll not be considered in this work. The possibility of hydroxy complexes has also been excluded in studies of the acetate and glycolate systems $(19,39,40)$ and will not be considered in this work. Furthermore, since the $\mathrm{pH}$ of the solutions was found never to exceed 4.2 , it can be seen from the hydrolysis constants of the rare-earth metals that any hydrolysis at such low $\mathrm{pH}$ values should be negligible $(42,43)$. It has also been shown that complex formation between the rare-earth ion and the undissociated carboxylic acid is negligible $(24,39,40)$. Hence any $\mathrm{pH}$ changes which occur when the buffer concentration is varied may be attributed to complexation of the carboxylate ligand with the rare-earth ion.

Assuming that the activities of the individual species taking part in the above reactions can be expressed by their concentrations, we have the following expressions for the mass-action constants of the complex forming equilibria.

$$
b_{1}=\frac{[M A]}{[M][A]} ; b_{2}=\frac{\left[M A_{2}\right]}{[M A][A]} ; \ldots . . b_{N}=\frac{\left[M A_{N}\right]}{\left[M A_{N-1}\right][A]}
$$

for the stepwise formation constants

and

$$
\beta_{1}=\frac{[M A]}{[M][A]} ; \beta_{2}=\frac{\left[\mathrm{MA}_{2}\right]}{[M][A]^{2}} ; \ldots \ldots \beta_{N}=\frac{\left[M A_{N}\right]}{[M][A]^{N}}
$$

for the overall formation constants: 
It is readily seen that $\beta_{N}=\prod_{i=1}^{N} b_{i}$.

The average ligand number $\bar{n}(44)$ is defined by Bjerrum as the average number of ligands bound to a metal ion. The total concentration of ligand bound to the metal $M$ is given by $\mathrm{MA}+2 \mathrm{MA}_{2}+3 \mathrm{MA}_{3}+\ldots+\mathrm{NMA}_{\mathrm{N}}$. The total concentration of metal present. in the system is given by $\mathrm{M}+\mathrm{MA}+\mathrm{MA}_{2}+$ $\mathrm{MA}_{3}+\ldots+\mathrm{MA}_{\mathrm{N}}$. The Iigand number $\overline{\mathrm{n}}$ is then given by

$$
\begin{aligned}
\bar{n} & =\frac{[M A]+2\left[M A_{2}\right]+\ldots \ldots+N\left[M A_{N}\right]}{[M]+[M A]+\ldots \ldots+\left[M A_{N}\right]} \\
& =\frac{b_{1}[A]+2 b_{1} b_{2}[A]^{2}+\ldots \ldots+N b_{1} b_{2} \ldots \ldots b_{N}[A]^{N}}{1+b_{1}[A]+b_{1} b_{2}[A]^{2}+\ldots \ldots+b_{1} b_{2} \ldots \ldots b_{N}[A]^{N}} \\
& =\frac{\beta_{1}[A]+2 \beta_{2}[A]^{2}+\ldots+N \beta_{N}[A]^{N}}{1+\beta_{1}[A]+\beta_{2}[A]^{2}+\ldots \ldots+\beta_{N}[A]^{N}} \\
& =\frac{\sum_{\sum}^{N} n \beta_{n}[A]^{n}}{\sum_{n=0}^{N} \beta_{n}[A]^{n}} \text { where } \beta_{0} \text { is understood to be unity. }
\end{aligned}
$$

When the overall composition of a solution is known and the concentration of any one of the species $M, M A, M A_{2}, \ldots$, $M A_{N}$, or $A$ can be determined independently, it is possible to calculate the various stability constants. In practice the 
hydrogen-ion concentration is accurately measured and [A] is then calculated from the iorization constant expression for the acid, that is

$$
\begin{aligned}
& K_{I}=\frac{\left[\mathrm{H}^{+}\right]\left[\mathrm{C}_{\mathrm{NaA}}+\left[\mathrm{H}^{+}\right]\right]}{\left[\mathrm{C}_{\mathrm{HA}}-\left[\mathrm{H}^{+}\right]\right]} \\
& {[\mathrm{A}]=\mathrm{K}_{\mathrm{I}} \frac{\left[\mathrm{C}_{\mathrm{HA}}-\left[\mathrm{H}^{+}\right]\right]}{\left[\mathrm{H}^{+}\right]}}
\end{aligned}
$$

This assumes that the only hydrogen ion present comes from the ligand acid.

There have been many methods devised for the calculation of stability constants, the method used for a specific ligand often being determined by the strength of the complex being studied. An extensive discussion of methods for the determination of stability constants is given by Rossotti (45). Only three of the several methods which would be suitable for the calculation of the stabllily constants of alpha-hydroxycarboxylate-rare-earth metal complexes will be discussed in this dissertation.

1. Fronaeus' method (46)

If only the mononuclear complexes $\mathrm{MA}, \mathrm{MA}_{2}, \ldots, \mathrm{MA}_{\mathrm{N}}$ are formed, we have equilibria of the form $M A_{N-1}+A \rightleftarrows M A_{N}$. The corresponding overall formation constant is defined by 
$\beta_{N}=\left[M A_{N}\right] /[M][A]^{N}$. With $\beta_{N}$ we can express $C_{M}$, the stoichiometric concentration of metal, and $C_{A}$, the stoichiometric concentration of $I$ igand as functions of $[A]$ and [M], that is

$$
\begin{aligned}
& C_{M}=[M] \cdot X \\
& C_{A}=[A]+[M] \cdot X^{\prime} \cdot[A]
\end{aligned}
$$

where $X=X([A])$ is defined by the equation

$$
X=1+\sum_{n=1}^{N} \beta_{n}[A]^{n}
$$

and

$$
X^{\prime}=\frac{d X([A])}{d[A]}
$$

The ligand number is given by

$$
\bar{n}=\frac{C_{A}-[A]}{C_{M}}
$$

where $C_{A}=C_{\mathrm{NaA}}+\left[\mathrm{H}^{+}\right]-\mathrm{C}_{\mathrm{H}} \cdot \mathrm{C}_{\mathrm{H}}$ is the concentration of any hydrogen ion not coming from the l1gand acid. Combination of Equations 1 and 2 and elimination of [M] yields $\bar{n} /[A]=X^{\prime} / X$, and after integration $\ln X\left([A]_{j}\right)=$ $\int_{0}^{[A]} j \bar{n} /[A]$ dA. This integration gives corresponding values of $X$ and $[A]$. The overall formation constants $\beta_{1}, \beta_{2}$, ..., $\hat{\beta}_{N}$ can now be calculated by successive extrapolation to $[A]=0$ of the functions $x_{1}, x_{2}, \ldots$ where 


$$
\begin{aligned}
& x_{1}=\frac{X-1}{[A]}=\beta_{1}+\beta_{2}[A]+\beta_{3}[A]^{2}+\ldots \\
& x_{2}=\frac{X_{1}-\beta_{1}}{[A]}=\beta_{2}+\beta_{3}[A]+\ldots
\end{aligned}
$$

and so on for the following constants. More detailed discussions of this method may be found in works by Bjerrum, Leden, and Fronaeus $(46,47,48)$. This method of computation has been used by Sonesson in his study of the glycolates (19), Karraker in his study of the glycolates and lactates (20), and Kolat in his study of the alpha-hydroxyisobutyrates (21). However, since this method involves tedious graphical integrations, it was not used in this research.

\section{Bjerrum's $(n-1 / 2)$ method (44)}

This method will give only a rough approximation to the values of the stability constants and was used only to get an initial set of values for the computer to begin its iterations on. The basic assumption made in this method, which is generally not a very good assumption, is that only the two complex species $M A_{N-1}$ and $M_{N}$ exist in solution to any significant extent. The concentrations of the species $M A_{N-2}$ and $M A_{N+I}$ in the solution must be negligible. Making 
use of this assumption, the system may be represented by the following equations.

$$
\begin{aligned}
& M A_{N-1}+A \rightleftarrows A_{N} \\
& b_{N}=\frac{\left[M A_{N}\right]}{\left[M A_{N-1}\right][A]} \\
& A_{\text {Total }}=(N-1)\left[M A_{N-1}\right]+N\left[M A_{N}\right]+A \text { where } A \text { is the } \\
& \quad \text { concentration of uncomplexed ligand. } \\
& M_{\text {Total }}=\left[M A_{N-1}\right]+\left[M A_{N}\right] \\
& \bar{n}=\frac{N-1+N A b_{N}}{I+A b_{N}}
\end{aligned}
$$

If $\bar{n}=N-1 / 2$, the last equation gives $b_{N}=(1 / A) \bar{n}=$ $N-1 / 2$.

3. The weighted least squares method of $W$. R. Stagg ( 41 . 49, 50)

This was the method used for computation of stability constants in this research. Define the mean ligand number $\bar{n}$ by $\bar{n}=(A-a) / M$ where $A$ is the total ligand concentration, $M$ is the total metal concentration, and a is the concentration of uncomplexed ligand. From the expression for the overall formation constant $\beta_{N}=\left[\mathrm{MA}_{\mathrm{N}}\right] /\left([\mathrm{M}][\mathrm{A}]^{\mathrm{N}}\right)$, the total 
concentration of the complex is $\left[M A_{N}\right]=\beta_{N}[M][A]^{N}$. The total Iigand concentration is then given by

$$
A=a+m \sum_{n=0}^{N} n k_{n} a^{n}
$$

where the first term represents the concentration of uncomplexed ligand and the second term that of complexed ligand and $m$ is the concentration of uncomplexed metal ion. The total metal concentration is given by

$$
M=m \sum_{n=0}^{N} \beta_{n} a^{n}
$$

The equation for $\overline{\mathrm{n}}$ then becomes

$$
\bar{n}=\frac{\sum_{n=0}^{N} n \beta_{n} a^{n}}{\sum_{n=0}^{N} \beta_{n} a^{n}} .
$$

In practice, the free ligand concentration is calculated from the accurately measured hydrogen-ion concentration and the previously determined ionization constant of the ligand acid, and $\bar{n}$ is calculated from the free ligand concentration and known composition of the solution. The $\bar{n}$ equation is then solved for the parameters $\beta_{n}$. It is necessary to use a weighting procedure to be described later in order to accomplish this.

Now rewrite the $\bar{n}$ equation in the following manner. 


$$
\begin{aligned}
& \sum_{n=0}^{N} \bar{n} \beta_{n} a^{n}=\sum_{n=0}^{N}\left(\frac{A-a}{M}\right) \beta_{n} a^{n}=\sum_{n=0}^{N} n \beta_{n} a^{n} . \\
& \sum_{n=0}^{N}(A-a) \beta_{n} a^{n}=\sum_{n=0}^{N} n M \beta_{n} a^{n} \\
& \sum_{n=0}^{N}\left(A_{i}-a_{i}-n M_{i}\right) \beta_{n} a_{i}^{n}=0
\end{aligned}
$$

The values of the total Iigand concentration, metal concentration, and free ligand concentration and estimates of the $\beta_{n}^{\prime}$ 's are inserted into Equation 3. Instead of getting zero, one gets a residual,

$$
U_{i}=\sum_{n=0}^{N}\left(A_{i}-a_{i}-n M_{i}\right) B_{n} a_{i}^{n}
$$

for a given set of data. This residual gives the deviation of the experimental $n$ versus a curve from the theoretical $\bar{n}$ versus a curve which is calculated using the values of the $\beta_{n}$ 's which are obtained. Minimizing this residual with respect to each of the $N$ parameters should give $N$ equations which cin be solved for each of the $N$ overall formation constants. Since the precision over a range of values of the free ligand concentration is not the same, it is necessary to use a weighting process where the data in more dilute solutions are weighed more heavily in order to 
obtain acceptable results.

$$
S=\sum_{i=1}^{I} W_{i} U_{i}^{2}
$$

is the weighted sum of squares of the residuals where the summation is taken over I sets of data. Then set

$$
\frac{\partial S}{\partial F_{n}}=0
$$

to minimize with respect to each of the parameters $\beta_{n}$. This gives $N$ equations involving the $N \beta_{n}$ parameters which may then be solved using Cramer's rule or matrix algebra. In the matrix technique, the standard deviation of each of the parameters may be calculated from the diagonal elements of the inverse of the matrix of the coefficients of the $\beta_{n}$ 's (49). This deviation is given by

$$
\sigma_{\beta_{n}}=\sqrt{\frac{r_{n n^{S}}}{I-N}}
$$

where $r_{n n}$ is the diagonal element of the inverse coefficient matrix. It must be emphasized that these deviations are the errors of internal consistency of the data points used to compute each parameter and are considerably smaller than the more realistic maximum possible error. These deviations relate to the relative errors of the data in a given experiment and do not reflect systematic errors which may have occurred in determining acià dissociation constants, 
concentrations of metal perchlorate and ligand buffer solutions, and so forth. When computations were made in which the input data were varied within their estimated maximum limits of error, it was found that the relative errors in $\beta_{1}, \beta_{2}$, and $\beta_{3}$ could be as great as $\pm 10 \%, \pm 25 \%$, and $\pm 50 \%$ respectively for a three parameter system. For a two parameter system, the relative errors could be as great as $\pm 25 \%$ and $\pm 50 \%$ for $\beta_{1}$ and $\beta_{2}$ respectively $(41)$.

The choice of weighting factor is arbitrary. The weighting factor used in this research is

$$
w_{1}=\frac{1}{\delta U_{1}^{2}}
$$

where.

$$
\delta U_{i}=\left(\frac{\partial U_{i}}{\partial a_{i}}\right) a_{1} p
$$

$p$ being the estimated relative probable error in the free ligand concentration (41). Use of the weighting factor hence insures that each point is weighted with respect to the relative precision of the measured free ligand concentration and with respect to the varianee of the residual with rree Ilgana concentration. In practice, the values of the total ligand concentration, the free ligand concentration, and the total metal concentration and estimates of the $\beta_{n}$ 's are inserted into Equation 3. Instead of getting a zero value expected if the $\beta_{n}$ 's were perfectly accurate 
estimates, one gets a resicual given by Equation 4. Making use of the weighting iactor as given by Equation 8 , the residual is minimized with respect to each $\beta_{n}$ parameter. If the value of $S_{\text {minimum }}$ obtained is not an acceptably small number, the above process is repeated until $\mathrm{S}_{\text {minimum }}$ is within the permissable limits.

In this research, the author made use of the services of the Iowa State University computer group and the IBM 7074 computer for calculation of the stability constants. The computer programs were written in such a manner that they would reiterate until successive values of the $\beta_{n}$ 's differed from each other by less than one part per thousand and until the standard deviation in each parameter was of smaller magnitude than the given parameter. Although the number of iterations was limited to 500, it was found that if these conditions were not satisfied within five or six iterations, they would not be satisfied at all. 


\section{EXPERIMENTAL PROCEDURE AND RESULTS}

The preparation and standardization of the rare-earth solutions used in this work were the same as for the solutions used by Stagg and Powell in the determination of the rare-earth isobutyrate, alpha-hydroxyisobutyrate, and $\alpha, \beta, \beta^{\prime}-$ trihydroxyisobutyrate stability constants.

An equimolar buffer solution of each acid and its sodium salt was prepared by adding a measured amount of carbonate-free standard sodium hydroxide solution to a roughly known amount of the acid solution. The carbonate was removed from the sodium hydroxide by the precipitation of sodium carbonate from a saturated sodium hydroxide solution (51) followed by filtration of the solution into a large polyethylene bottle containing boiled distilled water. l'he bottle was t'lushed with argon gas before and during the filtration. An aliquot of the resulting buffer was then titrated with standard potassium hydroxide solution prepared by the method of Powell and Hiller (52) to determine the free Iigand acid concentration. Both the sodium hydroxide and potassium hydroxide were standardized against accurately weighed amounts of pure potassium acid phthalate (51).

A series of solutions in which the total ligand anion concentration ranged from 0.001 to 0.04 molar was prepared, keeping the total rare-earth ion concentration constant at 
0.004 molar in each sample. With the methyltertiarybutylglycolate system, these concentrations were halved due to limited solubility of the chelates. The ionic strength was adjusted to 0.1 in each sample, using sodium perchlorate as the supporting electrolyte. Sodium perchlorate was used as the supporting electrolyte because, although perchlorate complexes have been reported, for most practical purposes, the complexing ability of the perchlorate ion is negligible $(53-55)$. The samples were then placed in a $25^{\circ} \mathrm{C}$ constant temperature bath and, after equilibration in the bath, the $\mathrm{pH}$ of each solution was measured. Knowing the $\mathrm{pH}$ of the solution and the ionization constant of the ligand acid makes possible the calculation of the concentration of free ligand anions, and ultimately the successive complexation constants, using the weighted least squares method and programming of W. R. Stagg and the IBM 7074 computer.

The 1onization constants of the ligand acids were determined at $25^{\circ} \mathrm{C}$ by preparing a series of solutions containing varying quantities of buffer, adjusting the ionic strength to 0.1 , and measuring the $\mathrm{pH}$. Knowing the hydrogen ion concentration, the ionization constants could be calculated from the ionization constant expression,

$$
K_{I}=\frac{\left[\mathrm{H}^{+}\right]\left(\mathrm{C}_{\mathrm{NaA}}+\left[\mathrm{H}^{+}\right]\right)}{\left(\mathrm{C}_{\mathrm{HA}}-\left[\mathrm{H}^{+}\right]\right)}
$$


See Appendix A for the values of the ionization constants. All $\mathrm{pH}$ measurements were made with the recently introduced Beckman Research pH Meter, Model 1019, which has the capability of reproducing $\mathrm{pH}$ readings to $0.001 \mathrm{pH}$ units. The potassium chloride-saturated calomel electrode was replaced by a sodium chloride-saturated calomel electrode to eliminate erratic behavior due to precipitation of slight.ly soluble potassium perchlorate in the fiber, and the instrument was standardized frequently during use against a buffer consisting of $1.000 \times 10^{-3}$ molar perchloric acid in 0.099 molar sodium perchlorate $(56)$. The $\mathrm{pH}$ range of the solutions studied was 3.3 to 4.2 .

Tables 1 through 4 show the values of the overall and stepwise formation constants of each of the four ligand aclds investigated in this research along with the standard deviations for the overall formation constants where these deviations are the errors of internal consistency as explained previously. Figure 1 shows the logarithms of the overall formation constants plotted against atomic number of the rare-earth metals. The lanthanum, cerium, praeseodymium, and neodymium constants for sach ucld were computed using a two parameter program. The remainder of the constants were computed using a three parameter program. In the two parameter system, data points in which $\bar{n}$ was apprectably greater than 1.5 and those in the three parameter system 
for which $\bar{n}$ appreciably exceeded 2.5 were excluded in calculating the constants. 
Table 1. Formation constants of the rare-earth isopropylglycolate chelate species $\left[25.0^{\circ} \mathrm{C} ; \mu=0.10\right.$

$\left(\mathrm{NaClO}_{4}\right) ; \mathrm{K}_{I}=2.03 \times 10^{-4} \mathrm{~J}$

Metal $\beta_{1}=b_{1} \times 10^{-2} \quad \beta_{2} \times 10^{-5} \quad \beta_{3} \times 10^{-7} \quad b_{2} \quad b_{3}$

$\begin{array}{lccccc}\text { La } & 1.49 \pm 0.03 & 0.09 \pm 0.01 & \ldots & 59 & \ldots \\ \mathrm{Ce} & 1.97 \pm 0.04 & 0.14 \pm 0.01 & \ldots & 74 & \ldots \\ \mathrm{Pr} & 2.37 \pm 0.07 & 0.21 \pm 0.01 & \ldots & 89 & \ldots \\ \mathrm{Nd} & 2.70 \pm 0.05 & 0.25 \pm 0.01 & -\cdots & 91 & \ldots \\ \mathrm{Sm} & 3.83 \pm 0.03 & 0.40 \pm 0.01 & 0.09 \pm 0.01 & 105 & 22 \\ \mathrm{Eu} & 4.27 \pm 0.06 & 0.49 \pm 0.02 & 0.19 \pm 0.01 & 115 & 29 \\ \mathrm{Gd} & 4.33 \pm 0.04 & 0.53 \pm 0.01 & 0.16 \pm 0.01 & 124 & 37 \\ \mathrm{~Tb} & 5.20 \pm 0.04 & 0.79 \pm 0.01 & 0.31 \pm 0.01 & 152 & 40 \\ \mathrm{Dy} & 6.2 \pm 0.1 & 1.02 \pm 0.04 & 0.57 \pm 0.03 & 166 & 55 \\ \mathrm{Ho} & 6.5 \pm 0.1 & 1.19 \pm 0.03 & 0.64 \pm 0.03 & 182 & 53 \\ \mathrm{Er} & 7.4 \pm 0.1 & 1.48 \pm 0.05 & 1.0 \pm 0.1 & 200 & 66 \\ \mathrm{Tm} & 8.3 \pm 0.1 & 1.80 \pm 0.06 & 1.4 \pm 0.1 & 219 & 78 \\ \mathrm{Yb} & 9.5 \pm 0.2 & 2.33 \pm 0.12 & 2.3 \pm 0.2 & 246 & 89 \\ \mathrm{Iu} & 10.3 \pm 0.3 & 2.60 \pm 0.14 & 2.6 \pm 0.2 & 258 & 98 \\ \mathrm{Y} & 5.41 \pm 0.04 & 0.83 \pm 0.02 & 0.33 \pm 0.01 & 155 & 40\end{array}$


Table 2. Formation constants of the rare-earth methylisopropylglycolate chelate species $\left[25.0^{\circ} \mathrm{C} ; \mu=0.10\right.$ $\left(\mathrm{NaClO}_{4}\right) ; \mathrm{K}_{\mathrm{I}}=1.71 \times 10^{-4} \mathrm{]}$

Metal $\beta_{1}=b_{1} \times 10^{-2} \quad \beta_{2} \times 10^{-5} \quad \beta_{3} \times 10^{-7} \quad b_{2} \quad b_{3}$

\begin{tabular}{|c|c|c|c|c|c|}
\hline La & $1.36 \pm 0.02$ & $0.06 \pm 0.01$ & -- & 47 & -- \\
\hline $\mathrm{Ce}$ & $1.42 \pm 0.05$ & $0.11 \pm 0.01$ & -- & 74 & - \\
\hline Pr & $2.03 \pm 0.05$ & $0.18 \pm 0.01$ & --- & 85 & -- \\
\hline Nd & $2.57 \pm 0.03$ & $0.25 \pm 0.01$ & --- & 102 & - \\
\hline $\mathrm{Sm}$ & $4.4 \pm 0.1$ & $0.59 \pm 0.03$ & $0.21 \pm 0.02$ & 135 & 36 \\
\hline $\mathrm{Eu}$ & $5.9 \pm 0.1$ & $0.89 \pm 0.01$ & $0.37 \pm 0.01$ & 155 & 42 \\
\hline Gd & $6.4 \pm 0.2$ & $1.12 \pm 0.04$ & $0.45 \pm 0.03$ & 182 & 47 \\
\hline $\mathrm{Tb}$ & $8.7 \pm 0.2$ & $1.81 \pm 0.07$ & $1.00 \pm 0.07$ & 214 & 51 \\
\hline Dy & $10.3 \pm 0.2$ & $2.6 \pm 0.1$ & $1.7 \pm 0.1$ & 246 & 59 \\
\hline Ho & $11.3 \pm 0.7$ & $2.9 \pm 0.1$ & $1.9 \pm 0.1$ & 276 & 65 \\
\hline $\operatorname{Tm}$ & $13.7 \pm 0.3$ & $4.5 \pm 0.2$ & $3.6 \pm 0.3$ & 324 & 85 \\
\hline$Y b$ & $15.9 \pm 0.5$ & $5.8 \pm 0.3$ & $5.3 \pm 0.4$. & 347 & 96 \\
\hline $\mathrm{Lu}$ & $16.5 \pm 0.5$ & $6.5 \pm 0.4$ & $6.3 \pm 0.5$ & 381 & 107 \\
\hline$Y$ & $9.2 \pm 0.1$ & $2.1 \pm 0.1$ & $1.18 \pm 0.06$ & 230 & 56 \\
\hline
\end{tabular}


Table 3. Formation constants of the rare-earth tertiarybutylglycolate chelate species $\left[25.0^{\circ} \mathrm{C} ; \mu=0.10\right.$ $\left.\left(\mathrm{NaClO}_{4}\right) ; \mathrm{K}_{I}=1.34 \times 10^{-4}\right]$

Metal $\beta_{1}=b_{1} \times 10^{-2} \beta_{2} \times 10^{-4} \quad \beta_{3} \times 10^{-6} \quad b_{2} \quad b_{3}$

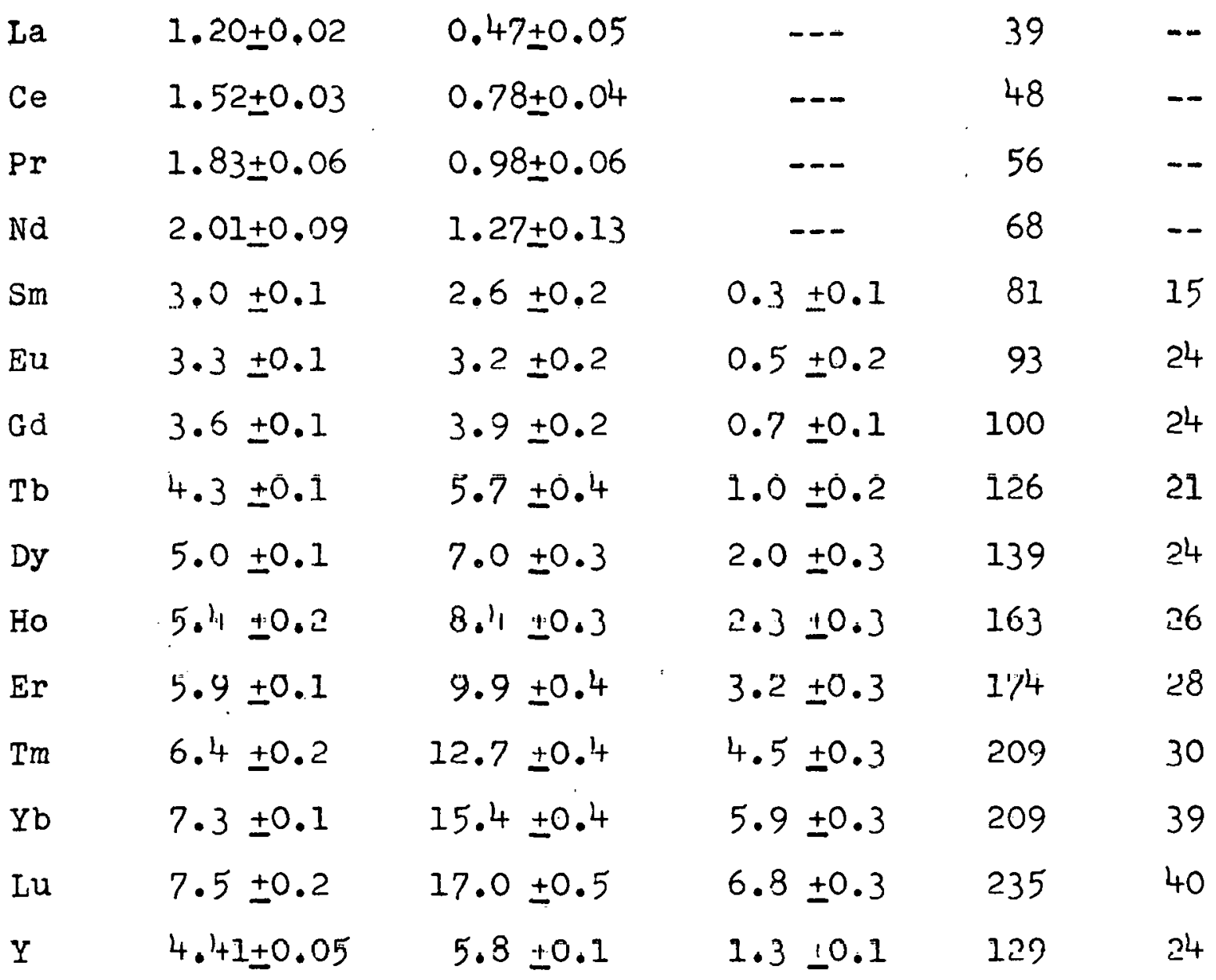


Table 4. Formation constants of the rare-earth methyltertiarybutylglycolate chelate species $\left[25.0^{\circ} \mathrm{C}\right.$; $\mu=0.10\left(\mathrm{NaClO}_{4}\right) ; \mathrm{K}_{\mathrm{I}}=1.14 \times 10^{-4}$ ]

Metal $\beta_{1}=b_{1} \times 10^{-2} \quad \beta_{2} \times 10^{-5}$

$\beta_{3} \times 10^{-7}$

$\mathrm{b}_{2}$

$b_{3}$

\begin{tabular}{lllcll}
\hline La & $1.31 \pm 0.02$ & $0.05 \pm 0.01$ & $\ldots$ & 34 & -- \\
$\mathrm{Ce}$ & $1.36 \pm 0.02$ & $0.08 \pm 0.01$ & $\ldots$ & 56 & -- \\
$\mathrm{Pr}$ & $3.01 \pm 0.06$ & $0.14 \pm 0.01$ & $\ldots$ & 71 & -- \\
$\mathrm{Nd}$ & $2.40 \pm 0.07$ & $0.19 \pm 0.02$ & $\ldots$ & 78 & -- \\
$\mathrm{Sm}$ & $4.6 \pm 0.1$ & $0.61 \pm 0.03$ & $0.10 \pm 0.02$ & 135 & 16 \\
$\mathrm{Eu}$ & $5.5 \pm 0.1$ & $0.38 \pm 0.02$ & $0.15 \pm 0.02$ & 159 & 17 \\
$\mathrm{Gd}$ & $6.4 \pm 0.1$ & $1.13 \pm 0.03$ & $0.26 \pm 0.03$ & 174 & 23 \\
$\mathrm{~Tb}$ & $9.2 \pm 0.1$ & $1.72 \pm 0.04$ & $0.92 \pm 0.05$ & 191 & 52 \\
$\mathrm{Dy}$ & $10.0 \pm 0.1$ & $2.28 \pm 0.03$ & $0.74 \pm 0.04$ & 230 & 32 \\
$\mathrm{Ho}$ & $11.2 \pm 0.2$ & $2.8 \pm 0.1$ & $1.1 \pm 0.1$ & 252 & 40 \\
$\mathrm{Er}$ & $12.1 \pm 0.1$ & $3.1 \pm 0.1$ & $1.2 \pm 0.1$ & 258 & 37 \\
$\mathrm{Tm}$ & $13.2 \pm 0.2$ & 3.710 .1 & $1.8 \pm 0.1$ & 282 & 49 \\
$\mathrm{Yb}$ & $15.5 \pm 0.2$ & $4.9 \pm 0.1$ & $2.2 \pm 0.2$ & 317 & 44 \\
$\mathrm{Lu}$ & $15.8 \pm 0.2$ & $5.2 \pm 0.1$ & $2.9 \pm 0.2$ & 332 & 55 \\
$\mathrm{Y}$ & $9.2 \pm 0.2$ & $1.81 \pm 0.06$ & $0.63 \pm 0.06$ & 200 & 35 \\
& & & & & \\
\hline
\end{tabular}




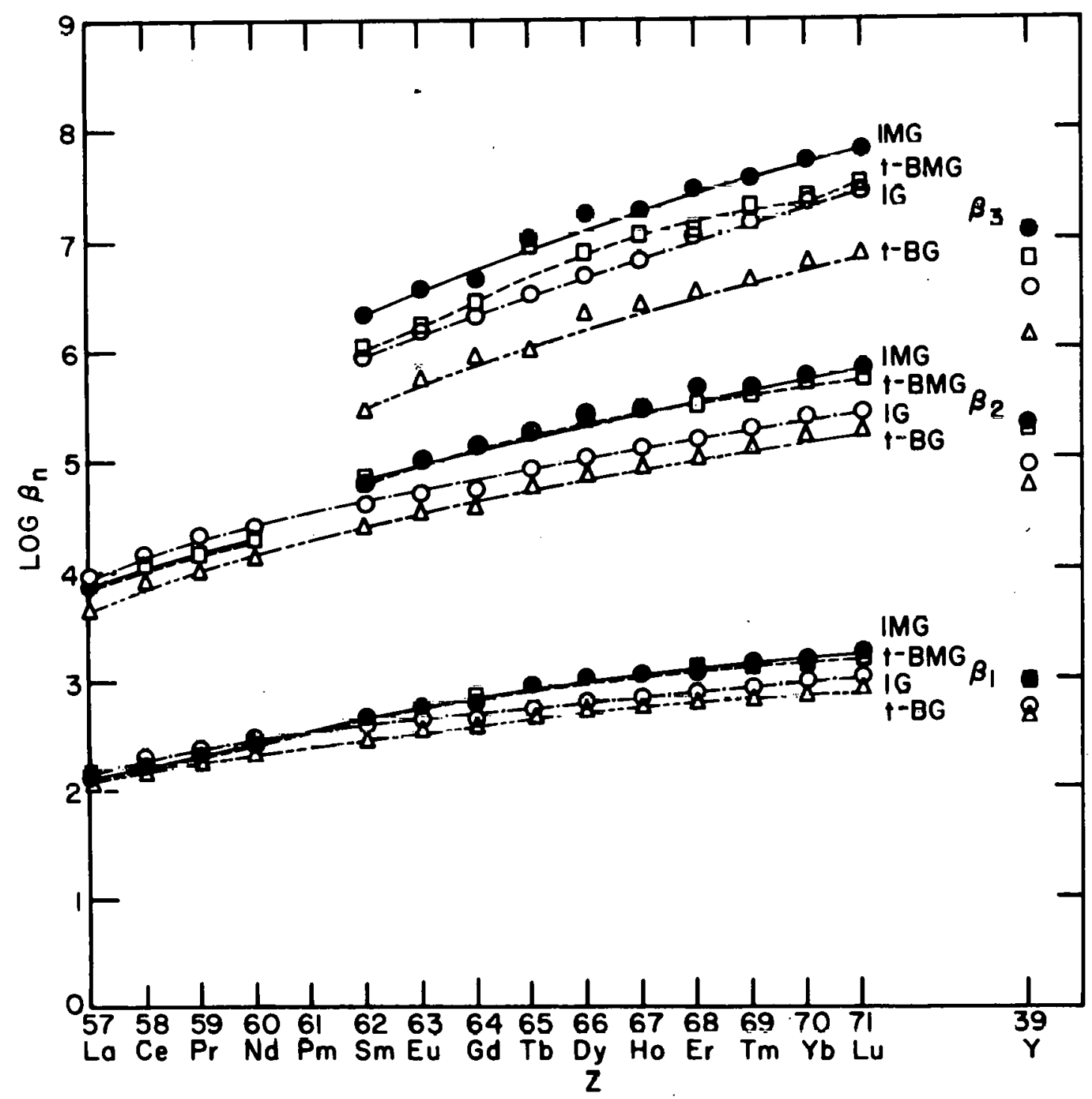

Figure 1. Overall formation constants of the rare-earth IG, IMG, $t-B G$ and $\mathrm{t}-\mathrm{BMG}$ complexes. 
IV. DISCUSSION

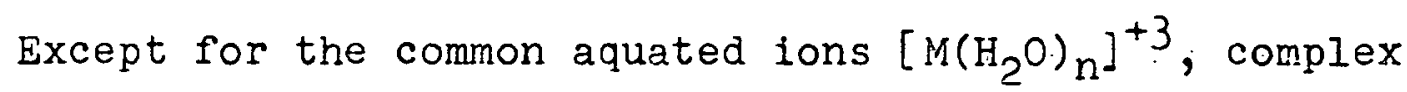
species of the rare-earth metals are limited in number and are appreciably stable only when derived from the strongest chelating agents, chiefly the nitrogen and oxygen containing 1iganòs. The rare earthsform ions which are much more similar to the alkaline earth metal ions than to the d-type transition metal ions which tend to be strong complex formers. This can be expected when it is realized that the transition metal species owe their properties to interaction between the d electrons of their valence shells and the available orbitals on the ligands. The f electrons of the rare earths are too well shielded to be available for extensive covalent bond formation and thus behave quite differently from the d electrons of the regular transition elements. The result is that each rare-earth ion is effectively an inert gas type ion, similar to the ions of the alkaline earth metals, that attracts ligands mainly by overall electrostatic forces. Furthermore, since the trivalent rare-earth ions are quite large with crystal radii ranging from 0.85 to $1.06 \AA$, this. electrostatic force of attraction tends to be diminished.

If electrostatic bonding in these complexes is signifi- cant, then, in terms of an extension of the Born Equation (57), $\Delta E=Z^{2} / 2 r[1-(1 / D)]$ where $\Delta E$ is the energy change on 
complexation of a gaseous ion of charge $Z$ and radius $r$ in a medium of dielectric constant $D$, a general increase in the stabilities of such chelates with decreasing crystal radil and stabilities of the yttrium complexes comparable with those of the analogous dysprosium and holmium species may be expected. A plot of $z^{2} / r$ against $\log \beta$ should yield a curve which increases linearly as the crystal radius of the rare earth decreases. From the curves for several monodentate, bidentate, and polydentate complexes shown in Figures 2 and 3 , it is evident that while the electrostatic theory is a reasonably good interpretation of the bonding in the light rare-earth complexes, other factors are significant among the heavy rare-earth complexes. Only for EDTA and HEDTA does the plot appear linear throughout the entire rare-earth series. Deviations from the electrostatic theory of bonding are also apparent from the fact that yttrium does not fall into the position dictated by its ionic radius. of course, the entire electrostatic bonding approach is based on the assumption that trends in crystal radii are kept in the solvated and coordinated species. Although there ex1sts ev1dence for the lanthanon contraction in many of the chelates investigated, it is probable that a smoothing out of size occurs and that differences in radii are correspondingly less pronounced than in binary ionic compounds. Participation of available $5 \mathrm{~d}$ orbitals is a possibility, 


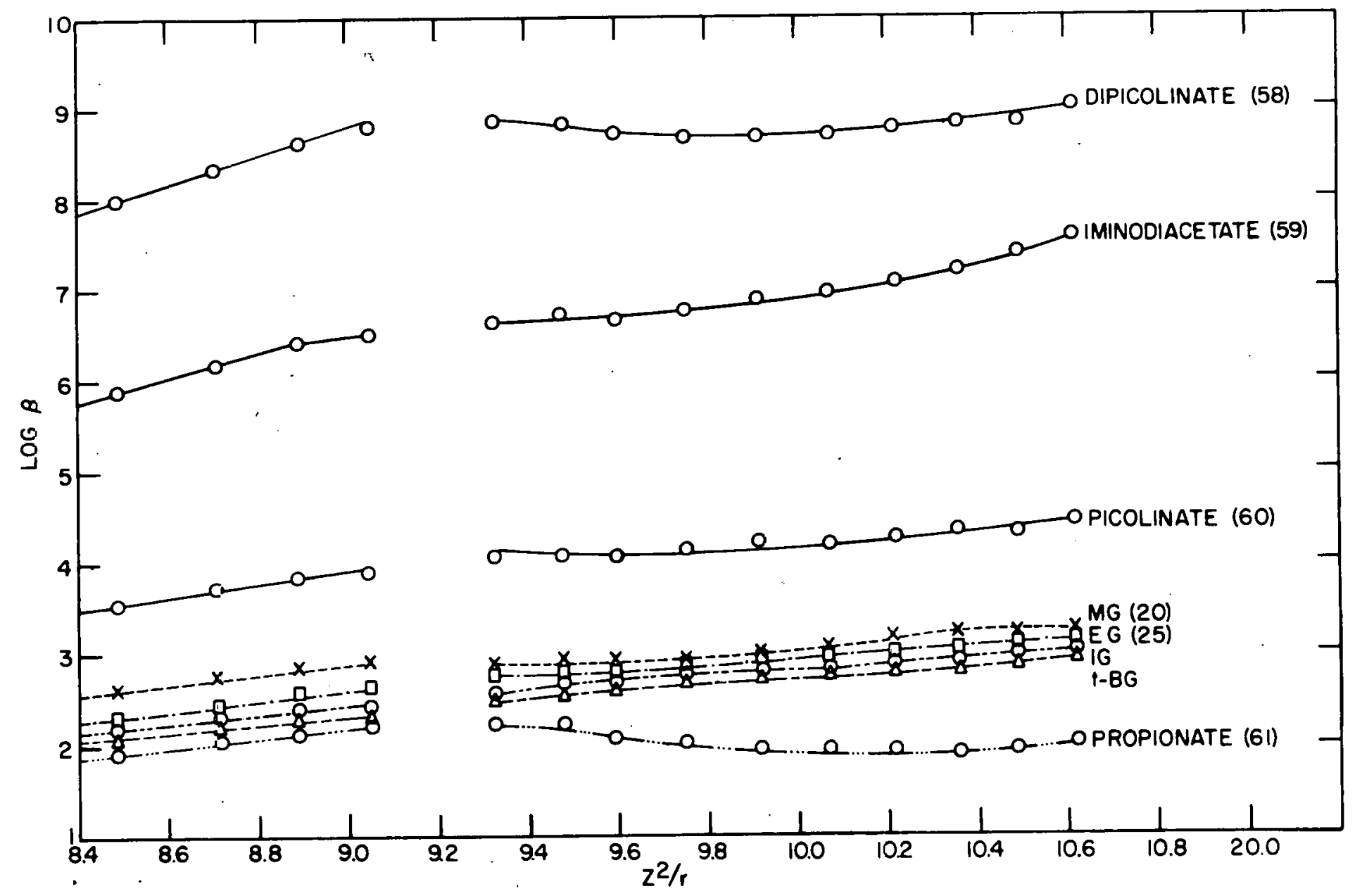

Figur 2 2. Stability as a function of ionic potential for some monodentate, bidentate, and tridentate rare-earth complexes. 


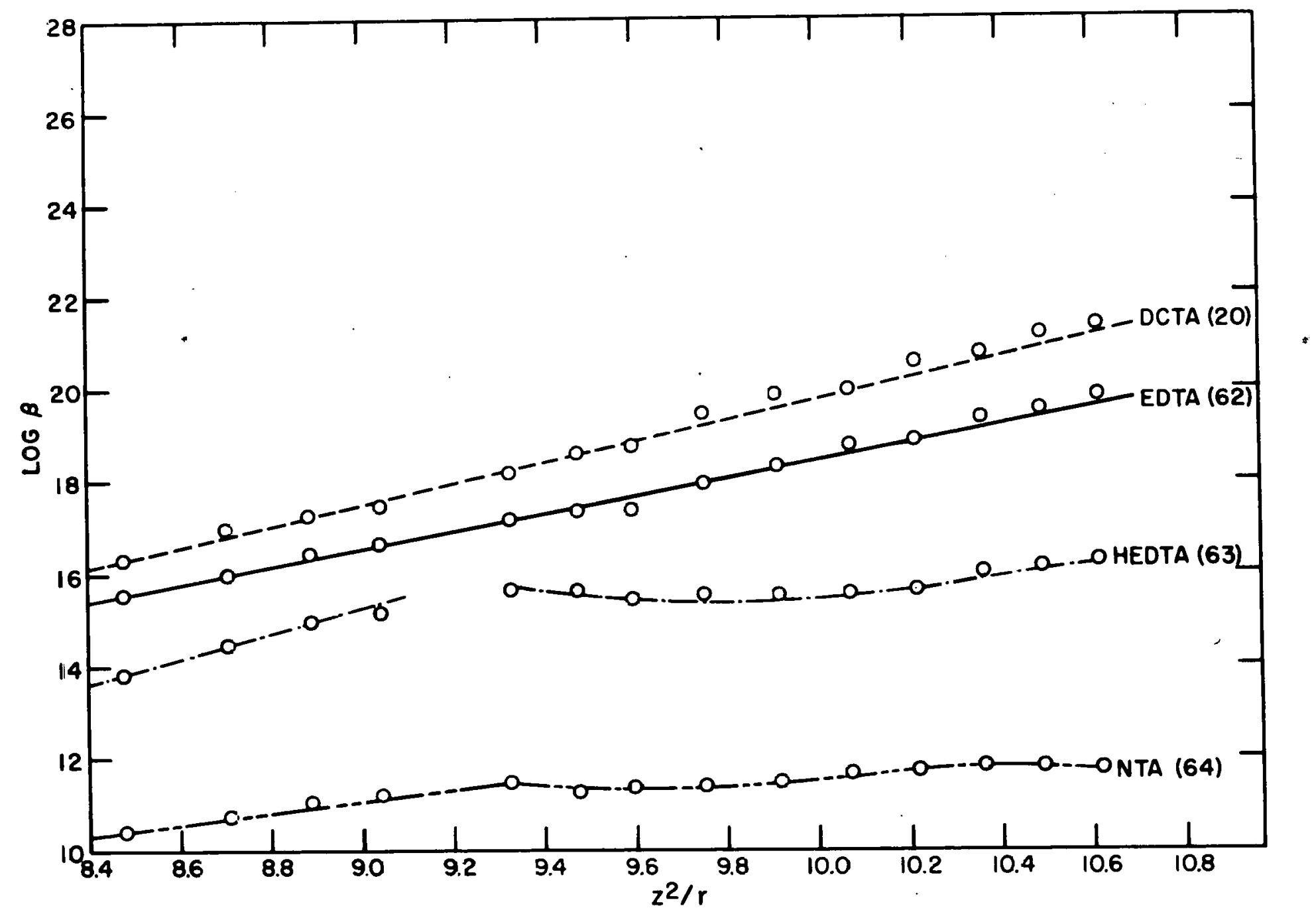

Figure 3. Stability as a function o ionic potentia- for some polydentate rare-earth complexes. 
but this is highly unlikely in the light of evidence that most binary and ternary rare-earth compounds have ionic properties. Furthermore, absorption spectra and magnetic susceptibility data indicate only perturbations of an environmental type, and show none of the profound changes expected if the responsible electrons were involved in bonding (6572). Therefore, it must be concluded that the ligands are held mainly by electrostatic or ionic interactions. The most stable chelated species of the rare earths are those derived from the aminopolycarboxylic acids. The anions of these acids are each capable of forming more than one chelate ring by utilizing the several oxygen and nitrogen donors that are available. In every instance a sufficient number of donors is present that 1:1 chelate species result. Increase in the number of like chelate rings in which a given cation can simultaneously participate increases the stability of the complex. For a given ligand there is a general increase in stability with decrease in ionic radius of the rare-earth metal. This increase is invariable in the region lanthanum to europium with a discontinuity often occurring at gadolinium. The rare earths heavier than gadolinium exhibit two distinctly different trends:

(a) A continuing and rather regular increase in stability with increasing atonic number, with the yttrium chelate occupying the position expected from the ionic radius of the 
$\mathrm{Y}^{+3}$ cation. NTA, EDTA, and DCTA are examples of ligands showing this behavior as illustrated in Figure 4.

(b) An increase in stability, followed by a decrease or leveling off to essential constancy as the atomic number of the rare earth increases, with the yttrium chelate occupying a position in the light rare-earth region and completely out of line with the stability expected on the basis of the size of the $\mathrm{Y}^{+3}$ ion. Examples of ligands which behave in this manner are HEDTA, DTPA, and monodentate ligands such as acetate, propionate, and isobutyrate anions. See illustrations of the stability trends of HEDTA and DTPA in Figure 5. The monodentate organic acid complexes which have been investigated show a steady increase in stability from lanthanum to samarium with the europium constant being approximately the same as the samarium constant. There is a sharp arop in stablitty at gadolinium with a subsequent continuing downward trend followed by a slight rising trend again toward the heavy end of the sertes. There is al.so $A$ tendency toward diminution in stability as the size of the alkyl group increases.

Included in this group of monodentate ligands are the aliphatic acids such as acetic, proptonic, and isobutyric. Also included are thioglycolic and methoxyacetic acids whose anions evidently function only as monodentate ligands with the rare-earth ions. See Figure 6. 


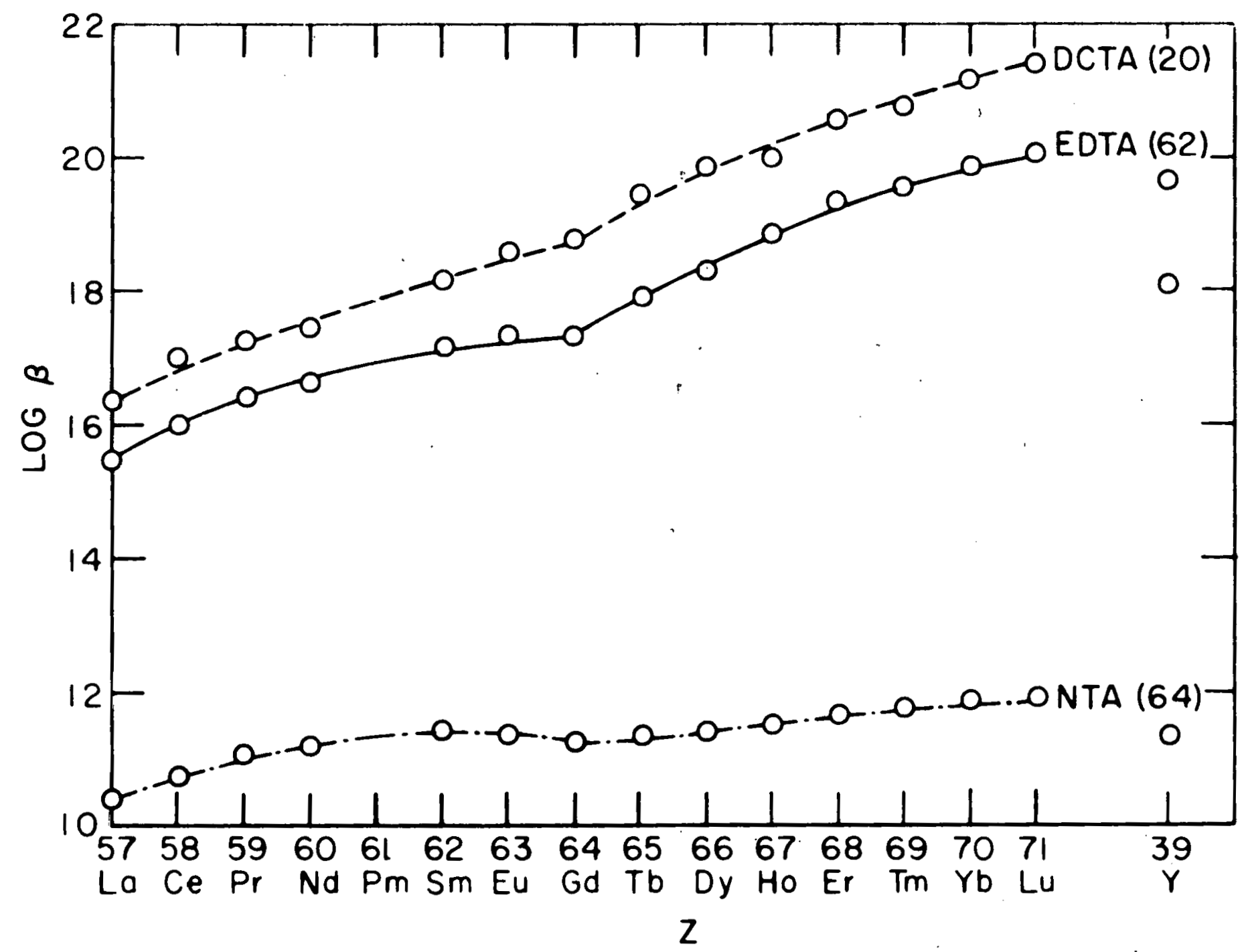

Figure 4. Stabilities cf the rare-earth NTA, EDTA, and DCTA chelates. 


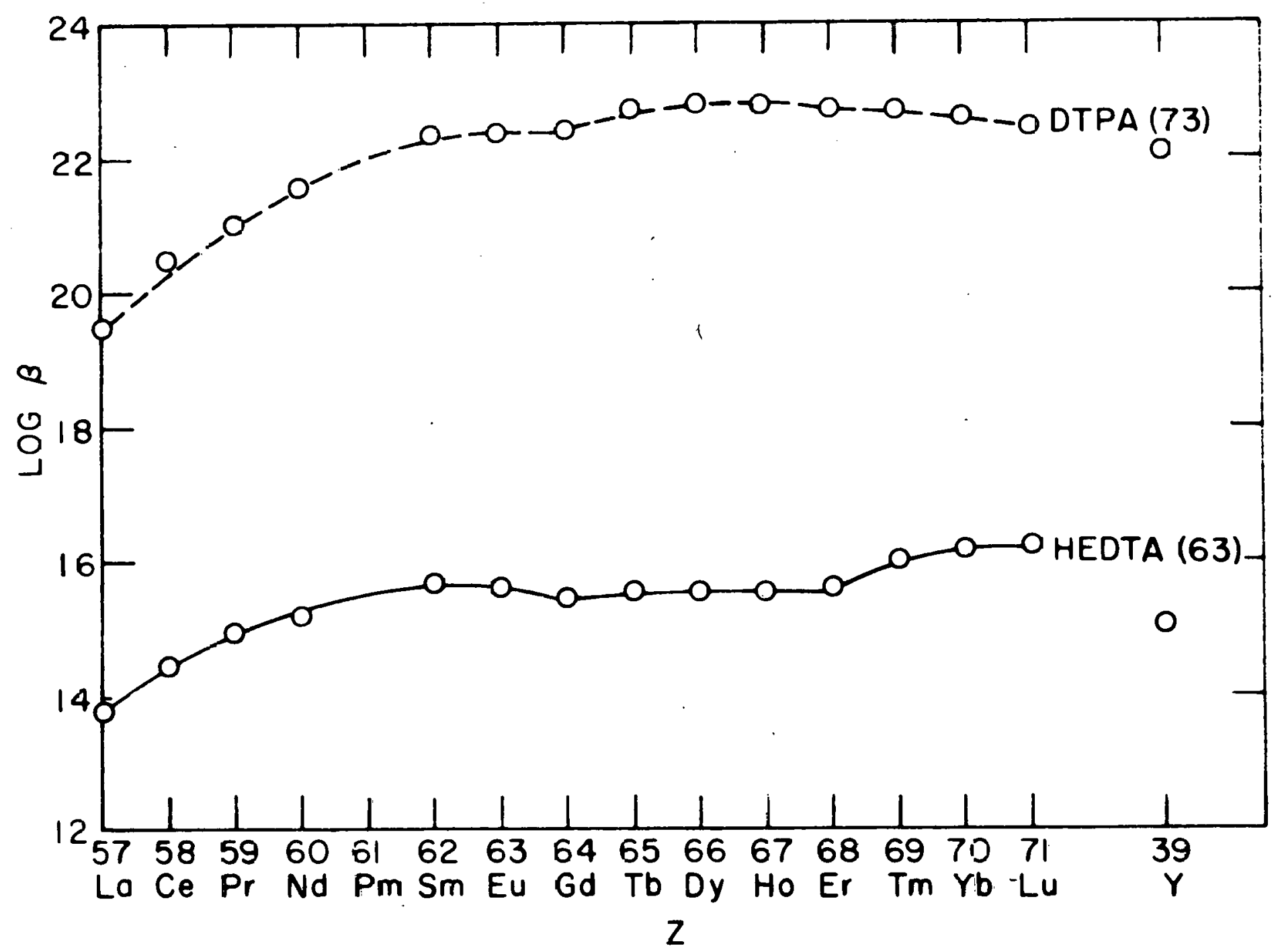

Figlire 5. Stabilities of the rare-earih HEDTA and DTPA chelates. 
A number of possible explanations can be given for the stability trends which have been osserved:

(a) The sudden drop in stability at gadolinium is due to a lack of ligand field stabilization of the half-filled $4 f$ suoshell of gadolinium similar to that observed for $z$ inc complexes ( $z$ inc has a filled 3 d subshell) (74,75). But this theory does not explain the continued decrease in stability subsequent to gadolinium. In fact, in the case of the isobutyrate ligand, a decrease in stability was noted at europium even before the $4 f^{7}$ configuration of gadolinium was reached. Furthermore, some liganas such as the higher molecular weight substituted glycolic acids exhibit no appreciable discontinuity in stability at gadolinium. Also an expected lowering of stability at lutetium which has a filled $4 \mathrm{f}$ subshell is not observed. Hence the ligand field interpretation of stability trends is no longer considered to be valid.

(b) The sudden discontinuity in stability at gadolinium is caused by an abnormally large change in ionic radius at gadolinium due to ligand field effects. However, this explanation suffers from the same general deficiencies as the preceding one.

(c) At about gadolinium, the carboxyl group changes from a bidentate coordinating group to a monodentate one due to the fact that it cannot wrap itself bidentately about the 


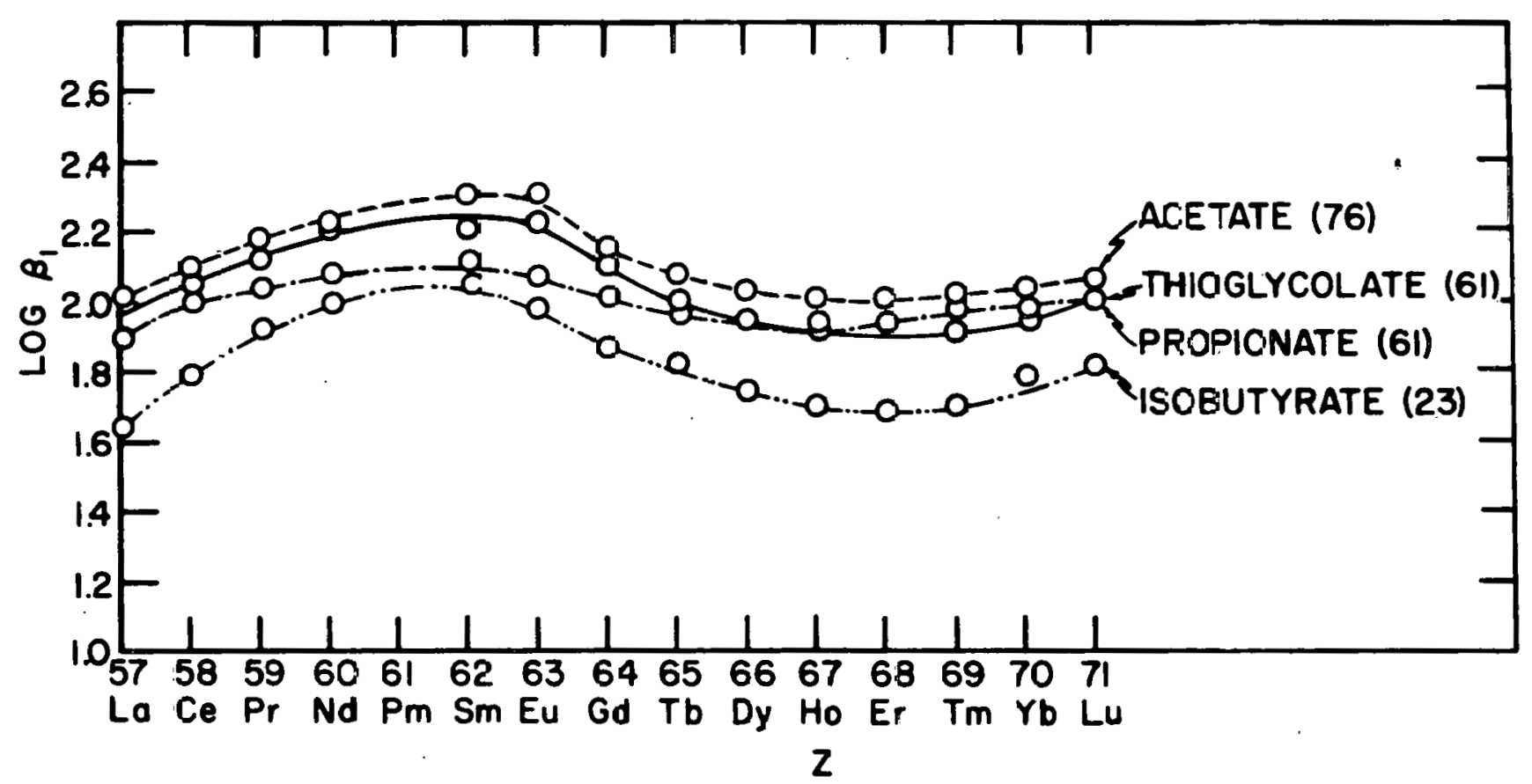

Figure $:$ Stabilities of some rare-earth monodentate complexes. 
smaller rare-earth ions. The slight rising trends observed toward the end of the series would again be due to the effect of the decrease in radius of the rare-earth ions for the monodentate carboxyl group. An analogous depression of the stability constants of the heavy rare earths was observed in the case of the $\alpha, \beta, \beta^{\prime}-t$ trihydroxyisobutyrate ligand (23) which was due to a change in dentate character of the ligand presumably occurring when only two of the three hydroxyl groups of the ligand find it possible to coordinate to the smaller yttrium group cations. Furthermore, the carboxyl group has been actually observed to act as a bidentate coordinating group in several transition metal acetate complexes $(77,78)$. This change in dentate character of the carboxyl group would appear to be a logical explanation for the stability trends observed for the monodentate ligands such as acetate and also for glycolate and some of its lower molecular weight homologues. With the heavier substituted glycolic acids, no appreciable discontinuity in stability is noted at gadolinium. This is perhaps due to the fact that the carboxyl group acts as a monodentate coordinating group throughout the entire rare-earth series f'or these ligands. Figure 7 shows the decreasing prominence of the gadolinium break as one goes to the heavier glycolic acids. A possible explanation for this linearity in the stability trends of these ligands is thal when groups bulkier than ethyl are 


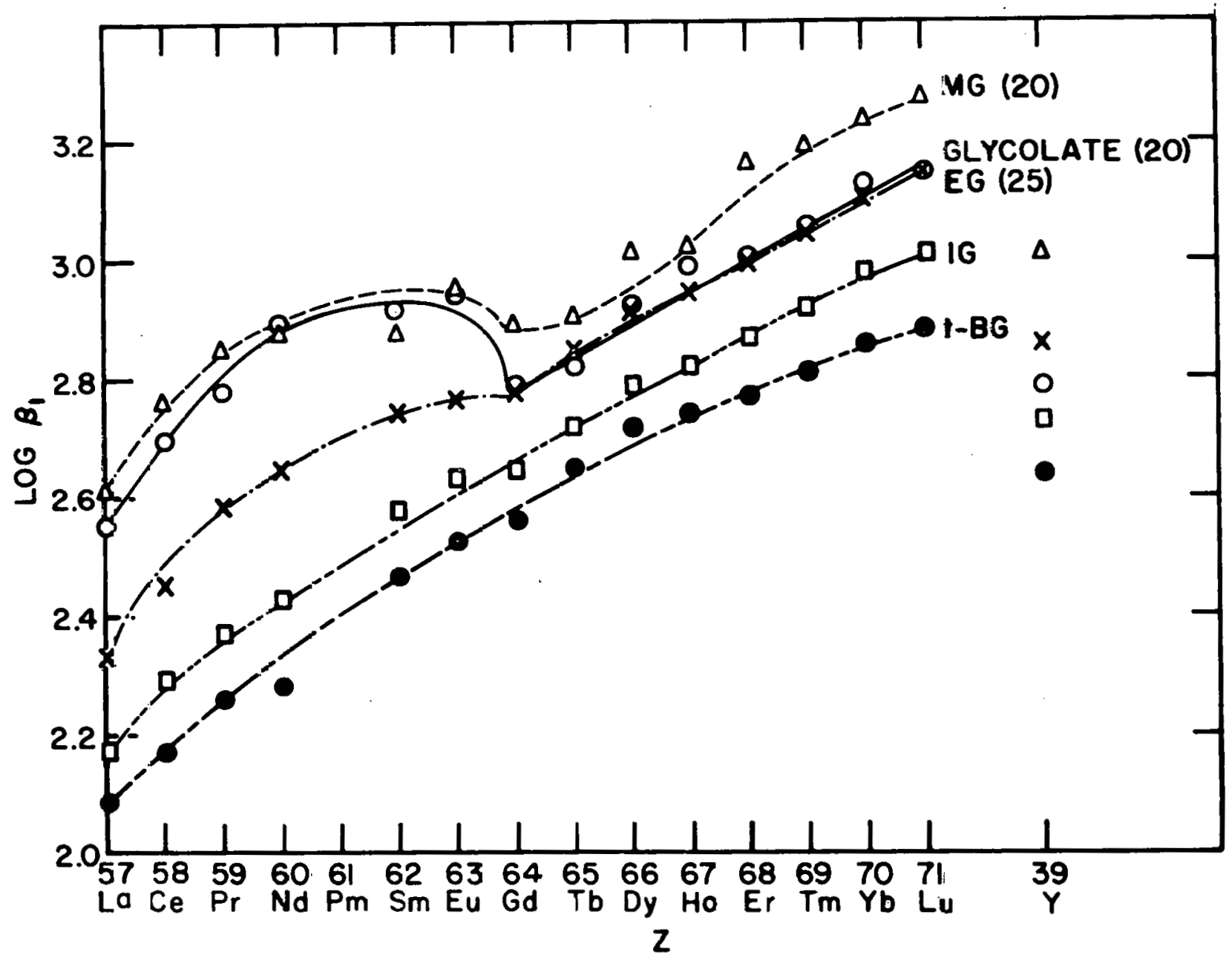

Figure 7. Stabilities of some rare-earth monosubstituted glycolate complexes. 
attached to glycolic acid, their rotation interferes with groups on other coordination sites of the rare-earth ion setting up vibrations in the complex which tend to prevent one of the carboxylate oxygens from coordinating to the metal.

It is evident that stabilities for the monodentate aliphatic acid complexes (acetate $>$ propionate $>$ isobutyrate) and for the monosubstituted glycolic acids (methylglycolic > ethylglycolic > isopropylglycolic > tertiarybutylglycolic) run contrary to what would be expected from the inductive effect, that is; affinity for hydrogen ion of these ligands decreases in the order isobutyrate > propionate $>$ acetate and tertiarybutylglycolate > isopropylglycolate > ethylglycolate > methylglycolate. A posstble explanation for these trends is given by the following facts. A hydrogen ion orients water molecules around it for only a relatively small distance whereas a trivalent rare-earth ion orlents water molecules around it for a much larger distance beyond its immediate coordination sphere. As the alkyl group of the carboxylic acid gets bulkier, it tends to disrupt the ordered structure of the water molecules to a larger degree as it approaches the metal ion, and hence experiences greater difficulty in coordinating to the metal. In other words, the ligands with the larger aliphatic groups do not experience much greater difficulty in approaching the hydrogen ion aue to its 
limited orientation of water molecules around it, and the inductive effect predominates giving lower ionization constants for the ligand acids. However, due to extensive orientation of water molecules around the trivalent rareearth ions, the ligands with the bulkier alkyl groups experience greater difficulty in approaching the metal ions, thus giving rise to less stable complexes.

The bidentate chelating agents investigated in this research have a different extent of alkyl substitution in the alpha carbon position. Two different effects, depending on the nature of the ligand, can exist in these complexes:

(a) Due to the inductive effects of substituents in position alpha to the carboxylate group, an increase in the degree of alkylation can be expected to increase the basicity of the hydroxy oxygen and, to a lesser extent, the carboxylate oxygen, thus increasing the strength of the complex. This is illustrated by the increasing trend in stabilities glycolate < methylgiycolate < dimethylglycolate. See Figure 8. Further support of this argument may be found in the case of the hydrogen ion which is small and little influenced by steric affects; thil $L \mathrm{~L}$, the Ionfation constants for the above three acids increase in the order dimethylglycolic < methylglycolic < glycolic. See Table 5 for a complete list of the ionization constants of the various substituted glycolic acids. 


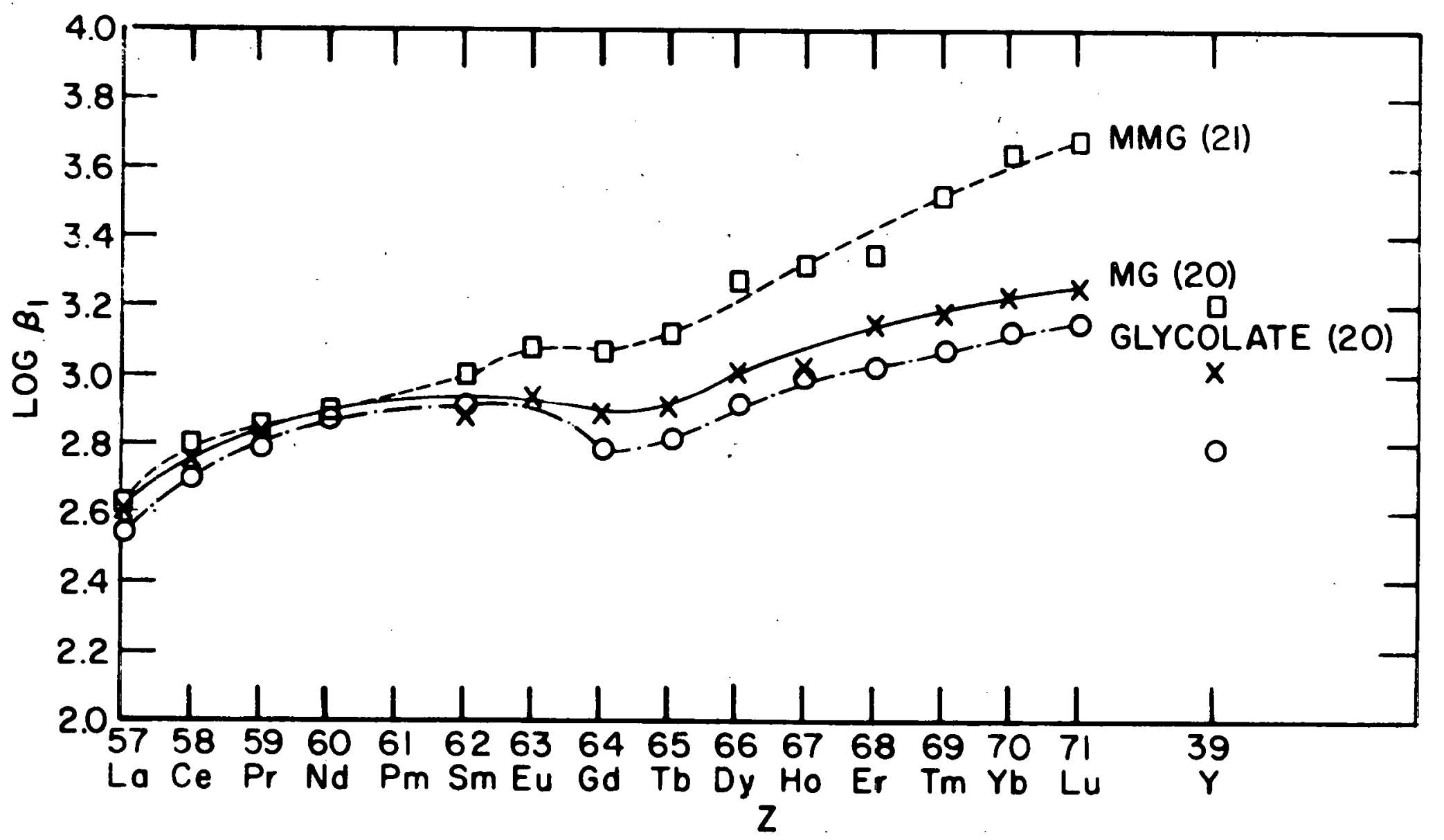

Figure 8. Stabilities of some rare-earth alpha-hydroxycarboxylate complexes. 
Table 5. Ionlzation constants of some substituted glycolic acids

\begin{tabular}{llll}
\hline \multicolumn{1}{c}{ Ac1d } & $\begin{array}{c}\text { Temperature } \\
\left({ }^{\circ} \mathrm{C}\right)\end{array}$ & $\mu$ & $\mathrm{K}_{\mathrm{I}} \times 10^{-4}$ \\
\hline & 20 & 0.1 & 2.72 \\
Glycolic (20) & 20 & 0.1 & 2.33 \\
Methylglycolic (20) & 20 & 0.1 & 1.61 \\
Dimethylglycolic (21) & 25 & 0.5 & 1.76 \\
Dimethylglycolic (23) & 25 & 0.1 & 2.13 \\
Ethylglycolic (25) & 25 & 0.1 & 1.77 \\
Methylethylglycolic (25) & 25 & 0.1 & 2.38 \\
Diethylglycolic (25) & 25 & 0.1 & 2.03 \\
Isopropylglycolic & 25 & 0.1 & 1.71 \\
Methylisopropylglycolic & 25 & 0.1 & 1.34 \\
Tertiarybutylglycolic & 25 & 0.1 & 1.14 \\
Methyltertiarybutylglycolic & 25 & 0.1 & 2.27 \\
Ethylisopropylglycolic (26) & 25 & & \\
\hline
\end{tabular}


(b) The complexing ability of the least alkylated ligand is favored due to lack of steric hindrance, especially as the number of ligands attached to a central atom increases. Furthermore, a bulky group has greater difficulty in approaching a metal ion since it causes greater disruption of the orfented layers of water molecules around the ion. However, a methyl group in place of a hydrogen atom can increase the stability of the chelate, especially in the case of the smaller yttrium group cations, because it gives a smaller, more favorable bond angle between the hydroxyl and carboxyl groups and closes the chelate around the metal ion more efficiently. See illustrations in Figures 8 - 11 . Repulsion between the more bulky alkyl groups and the fact that they need more space in which to rotate than does a methyl group could decrease the hydroxyl-carboxyl bond angle to such a great extent that the fit of the chelate around the metal ion would be poorer. If this is true, one would expect the lanthanum stability constants to be depressed to a greater extent than the lutetium constants as these groups become more bulky. An illustration of this principle is the fact that the enhancements of the stabilities of the methylethylglycolate over the ethylglycolate, methylisopropylglycolate over the isopropylglycolate, and methyltertiarybutylglycolate over the tertiarybutylglycolate complexes are much more pronounced for the heavy rare earths, showing the 


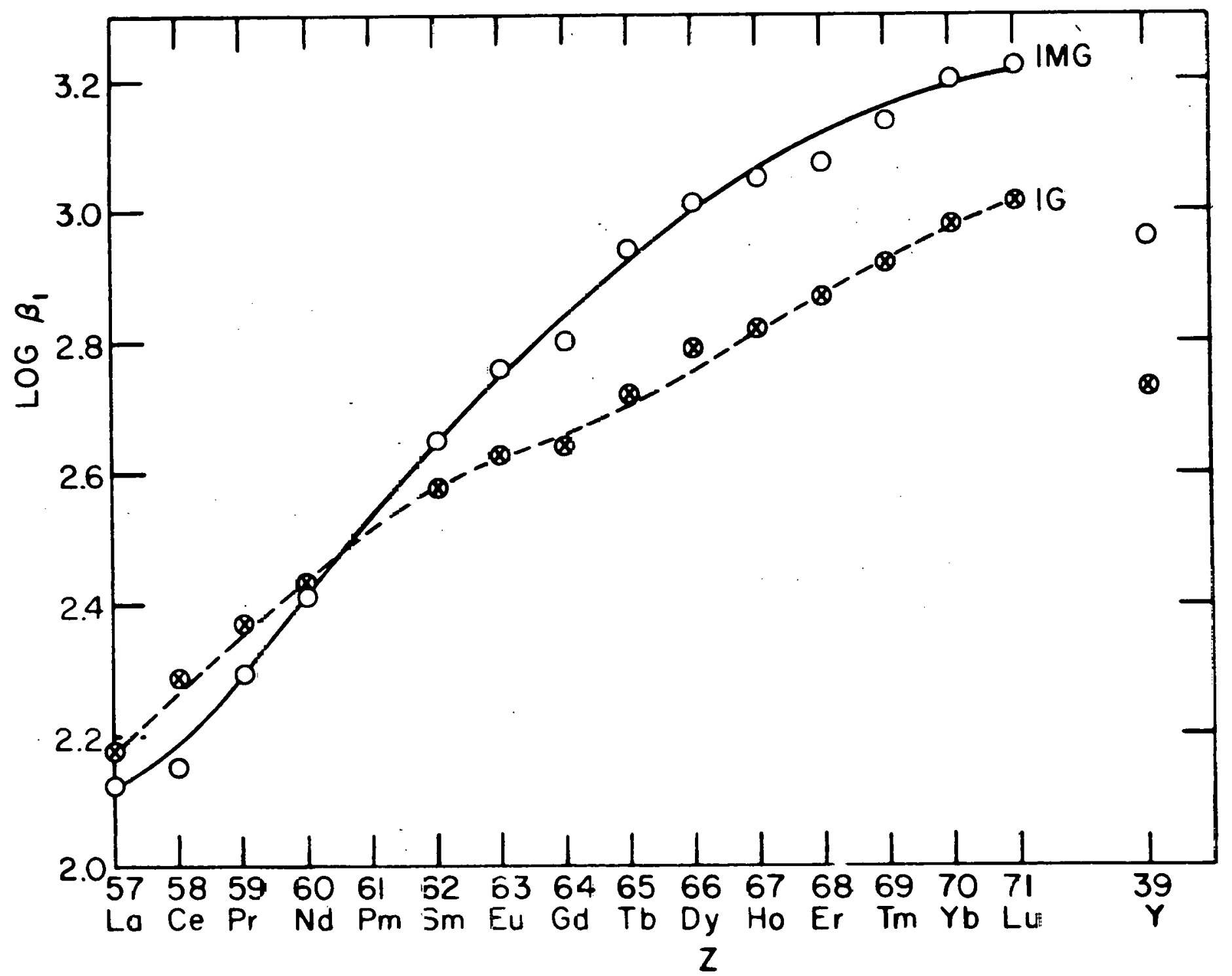

Figure 9. Stabilities of the rare-earth IG and IMG complexes. 


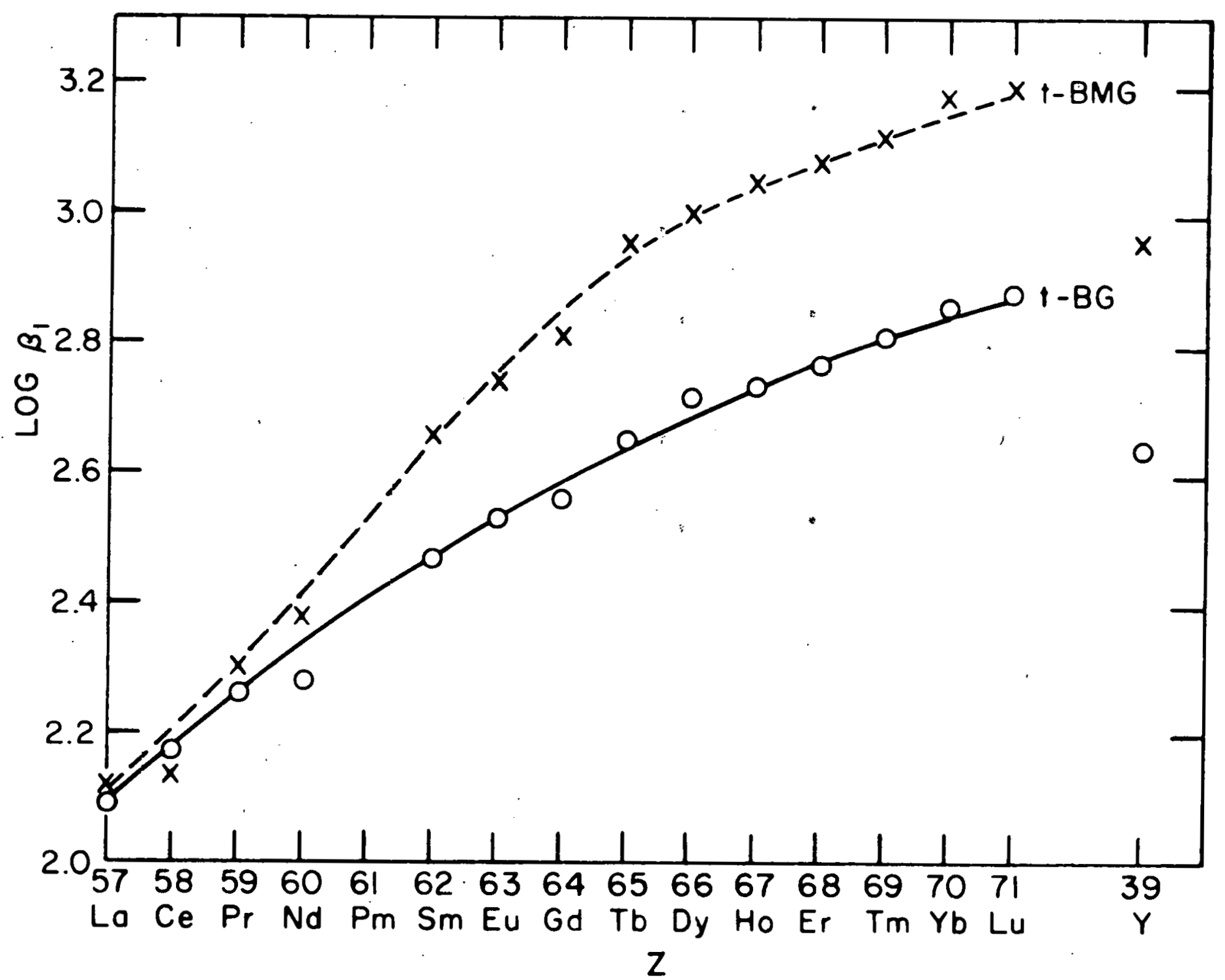

Figure 10. Stabilities of the rare-earth $t-B G$ and $t-B M G$ complexes. 


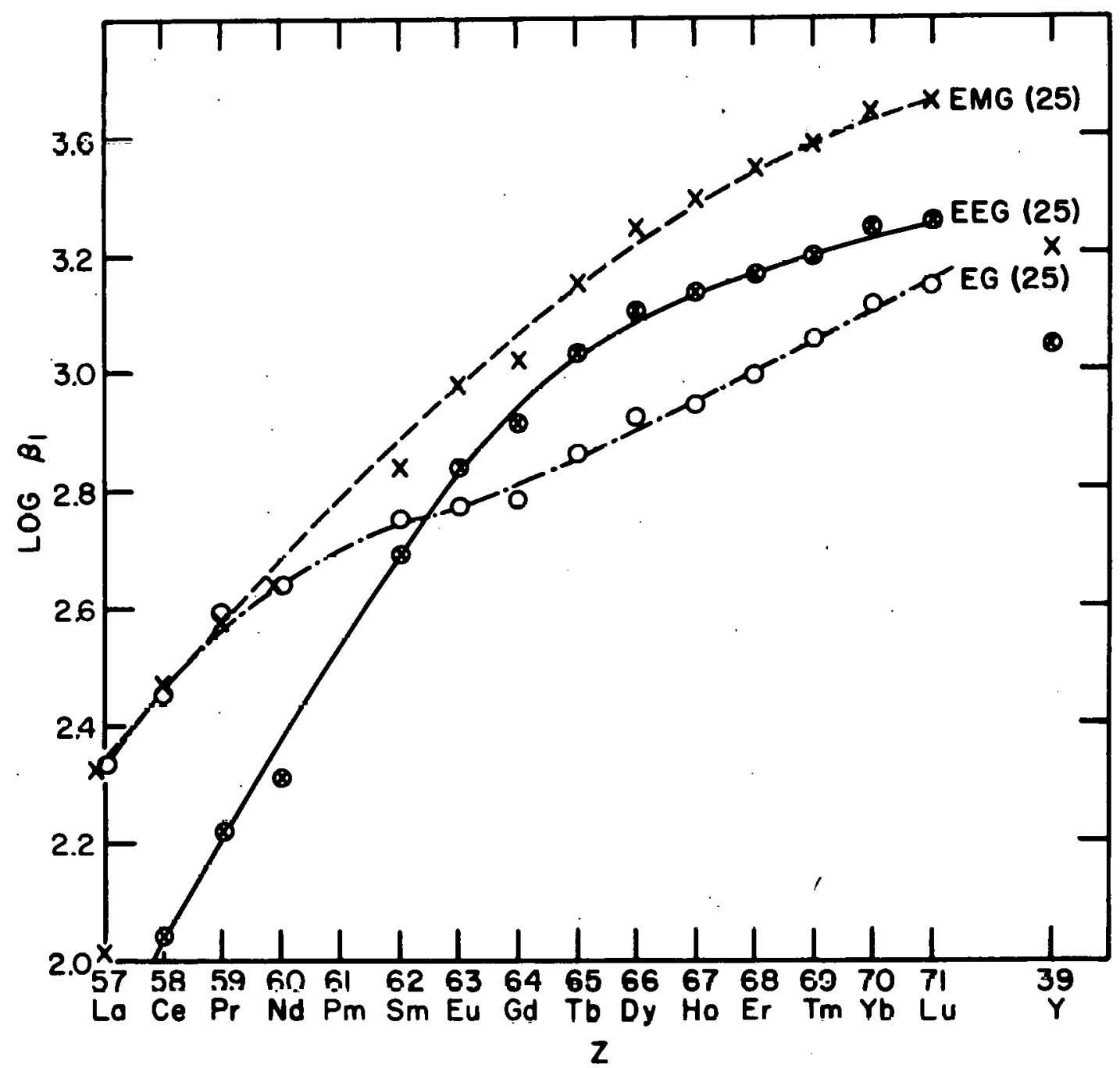

Figure 1'1. Stabilities of the rare-earth EG, EMG, and EEG complexes. 
more efficient closing of the bond angle due to the methyl group about the smaller yttrium group ions. See Figures $8-11$.

When a second alkyl radical on a ligand gets larger as in going from dimethylglycolate to methylethylglycolate or methylethylglycolate to diethylglycolate, the affinity of the alpha-hydroxycarboxylate anion decreases for both hydrogen ion and rare-earth ions. Note diminuition of stability of the diethylglycolate chelates in Figure 11. This decreased stability is most pronounced for the larger cerium group cations. This is due to a steric effect; that is, an ethyl group requires more space in which to rotate freely than does a methyl group. For rotation in an unsynchronized manner without the two alkyl groups colliding, two ethyl groups require as much space as two tertiarybutyl groups or any comblnation of ethyl, isopropyl, and tertiarybutyl radicals. This fact explains the increase in ionization constant in going from methylethylglycolate to diethylglycolale. It appears that a slight reduction of the angle between the hydroxyl and carboxyl groups due to replacing an alpha hydrogen by a methyl group in a singly substituted glycolate ligand does not negate a tendency for improved bonding of hydrogen ion to the anion due to the greater inductive effect of the methyl group as compared to hydrogen, and gives a better fit of the electron donating hydroxyl and carboxyl 
groups around the hydrogen ion and the heavier rare-earth ions (whose chelates have their stabilities enhanced to a greater extent than do their lighter counterparts). Adding a second ethyl group, however, reduces the angle between the electron donating groups to too great an extent and causes decreased stabllity for both light and heavy rare-earth complexes as well as reduced affinity for hydrogen ion. This reduced stability of the complexes is most pronounced for the larger light rare earths for which the reduced bond angle would be expected to give the poorest fit. See Figure 11. For groups more complex than ethyl, further shrinkage in the angle between the hydroxyl and carboxyl groups should be negligible, so that the hydrogen ion should be affected only by the greater electron density on the donor atoms due to the enhanced inductive effect of the bulkier alkyl grouns. But the larger rare-earth ions are hampered further in thelr approach to the electron donating groups by the greater bulkiness of the more complex alkyl substituents. This thus explains the decreased stability of the rare-earth chelates formed with the more complex alpha-hydroxycarboxylate ligands even though affinity for hydrogen lon Increases.

It is worthwhile to examine the ratios of successive formation constants for the rare-earth alpha-hydroxycarboxylate chelates and to consider their implications with regard to steric hindrance, coordination number, and geometry. 
Table 6 shows the ratios $b_{1} / b_{2}$ and $b_{2} / b_{3}$ for seven different substituted glycolic acids.

The abnormally high $b_{2} / b_{3}$ values observed in the cases of tertiarybutylglycolate and methyltertiarybutylglycolate indicate an appreciable amount of steric hindrance in these complexes. The unusually small $b_{3}$ values in these cases shows that a third ligand has considerable difficulty approaching a rare-earth ion which is already surrounded by two other bulky groups. For the diethylglycolate complexes both the $b_{1} / b_{2}$ and $b_{2} / b_{3}$ values are found to be anomalously high. Apparently even a second ligand has difficulty in approaching a metal ior to which one of these ligands is attached due to the large amount of space required for the free rotation of two ethyl groups, thus blocking otherwise available coordination sites of the metal.

The statistical effect related to the $b_{n}$ values should be proportional to the number of ways of forming $M_{n}$ species divided by the number of ways that $\mathrm{ML}_{n-1}$ can be formed from i. $L_{n}$ by splitting off a bidentate ligand (44). For example, $b_{1}: b_{2}: b_{3}$ for a bidentate ligand bonding to a hexacoordinate cation with the octahedral configuration would be $12 / 1: 5 / 2$ : $4 / 15$, so that $b_{1} / b_{2}$ should equal 4.80 and $b_{2} / b_{3}$ should equal 9.38 if other effects are not considered. One would not expect the rare earth coordination sites to have this configuration, since $\bar{n}$, the average number of ligands bound 
Table 6. Ratios of successije formation constants of some rare-earth-alphahydroxycarboxylate complexes. First column under each acid shows ratio $b_{1} / b_{2}$. Second column shows ratio $b_{2} / b_{3}$

\begin{tabular}{|c|c|c|c|c|c|c|c|c|c|c|c|c|c|c|}
\hline \multirow{2}{*}{$\begin{array}{l}\text { Metal } \\
\mathrm{La} \\
\mathrm{Ce}\end{array}$} & \multicolumn{2}{|c|}{ EG } & \multicolumn{2}{|c|}{ EMG } & \multicolumn{2}{|c|}{ EEG } & \multicolumn{2}{|c|}{ IG } & \multicolumn{2}{|c|}{$t-B G$} & \multicolumn{2}{|c|}{ IMG } & \multicolumn{2}{|c|}{$t-B M G$} \\
\hline & $\begin{array}{l}3.4 \\
3.7\end{array}$ & $\overline{--}$ & $\begin{array}{l}3.9 \\
3.6\end{array}$ & $=-$ & $\begin{array}{l}3.4 \\
2.5\end{array}$ & $=--$ & $\begin{array}{l}2.5 \\
2.6\end{array}$ & $\cdots$ & $\begin{array}{l}3.1 \\
3.0\end{array}$ & --- & $\begin{array}{l}3.3 \\
1.9\end{array}$ & --- & $\begin{array}{l}3.4 \\
2.4\end{array}$ & $=-$ \\
\hline $\mathrm{Pr}$ & $\begin{array}{l}4.7 \\
4.8\end{array}$ & $\begin{array}{l}4.2 \\
3.4\end{array}$ & $\begin{array}{l}4.4 \\
4.6\end{array}$ & $\overline{--}$ & $\begin{array}{l}3.1 \\
3.1\end{array}$ & --- & $\begin{array}{l}2.7 \\
2.9\end{array}$ & -- & $\begin{array}{l}3.4 \\
3.2\end{array}$ & --- & $\begin{array}{l}2.4 \\
3.2\end{array}$ & $\overline{---}$ & $\begin{array}{l}2.8 \\
3.1\end{array}$ & - \\
\hline $\begin{array}{l}\mathrm{Sm} \\
\mathrm{Eu}\end{array}$ & $\begin{array}{l}4.4 \\
4.4\end{array}$ & $\begin{array}{l}3.8 \\
3.8\end{array}$ & $\begin{array}{r}3.6 \\
4.5\end{array}$ & $\begin{array}{l}4.1 \\
2.9\end{array}$ & $\begin{array}{l}4.9 \\
5.2\end{array}$ & $\begin{array}{l}8.2 \\
9.2\end{array}$ & $\begin{array}{l}3.6 \\
3.7\end{array}$ & $\begin{array}{l}4.8 \\
2.9\end{array}$ & $\begin{array}{l}3.4 \\
3.4\end{array}$ & $\begin{array}{l}7.3 \\
6.1\end{array}$ & $\begin{array}{l}3.3 \\
3.8\end{array}$ & $\begin{array}{l}3.7 \\
3.7\end{array}$ & $\begin{array}{l}8.4 \\
3.5\end{array}$ & 9.4 \\
\hline $\begin{array}{l}\mathrm{Gd} \\
\mathrm{Tb}\end{array}$ & $\begin{array}{l}4.2 \\
4.1\end{array}$ & $\begin{array}{l}3.1 \\
3.0\end{array}$ & $\begin{array}{l}5.0 \\
4.4\end{array}$ & $\begin{array}{l}2.8 \\
3.4\end{array}$ & $\begin{array}{l}7.5 \\
7.6\end{array}$ & $\begin{array}{l}7.9 \\
9.9\end{array}$ & $\begin{array}{l}3.5 \\
3.4\end{array}$ & $\begin{array}{l}4.3 \\
3.8\end{array}$ & $\begin{array}{l}3.3 \\
3.2\end{array}$ & $\begin{array}{l}6.0 \\
7.4\end{array}$ & $\begin{array}{l}3.5 \\
4.0\end{array}$ & $\begin{array}{l}3.9 \\
4.1\end{array}$ & $\begin{array}{l}3.7 \\
4.8\end{array}$ & $\begin{array}{l}7.6 \\
3.7\end{array}$ \\
\hline $\begin{array}{l}\text { Dy } \\
\text { Ho }\end{array}$ & $\begin{array}{l}4.1 \\
3.5\end{array}$ & $\begin{array}{l}3.1 \\
4.2\end{array}$ & $\begin{array}{l}4.3 \\
4.8\end{array}$ & $\frac{3}{3} \cdot 3$ & $\begin{array}{l}3.4 \\
3.4\end{array}$ & $\begin{array}{l}8.7 \\
8.0\end{array}$ & $\begin{array}{l}3.7 \\
3.6\end{array}$ & $\begin{array}{l}3.0 \\
3.4\end{array}$ & $\begin{array}{l}3.6 \\
3.5\end{array}$ & $\begin{array}{l}4.8 \\
5.8\end{array}$ & $\begin{array}{l}4.2 \\
4.1\end{array}$ & $\begin{array}{l}4.2 \\
4.2\end{array}$ & $\begin{array}{l}4.3 \\
4.4\end{array}$ & $\begin{array}{l}7.2 \\
6.3\end{array}$ \\
\hline $\begin{array}{l}\mathrm{Er} \\
\mathrm{Tm}\end{array}$ & $\begin{array}{l}3.7 \\
3.8\end{array}$ & $\begin{array}{l}3.3 \\
3.1\end{array}$ & $\begin{array}{l}4.6 \\
6.9\end{array}$ & $\begin{array}{l}3.3 \\
2.1\end{array}$ & $\begin{array}{l}7.9 \\
7.8\end{array}$ & $\begin{array}{l}9.1 \\
8.9\end{array}$ & $\begin{array}{l}3.7 \\
3.8\end{array}$ & $\begin{array}{l}3.0 \\
2.9\end{array}$ & $\begin{array}{l}3.5 \\
3.2\end{array}$ & $\begin{array}{l}5.3 \\
5.7\end{array}$ & $\begin{array}{l}4.0 \\
4.2\end{array}$ & $\begin{array}{l}3.9 \\
3.8\end{array}$ & $\begin{array}{l}4.7 \\
4.7\end{array}$ & $\begin{array}{l}7.0 \\
5.8\end{array}$ \\
\hline $\begin{array}{l}Y b \\
\mathrm{Lu}\end{array}$ & $\begin{array}{l}3.8 \\
3.7\end{array}$ & $\begin{array}{l}3.1 \\
3.0\end{array}$ & $\begin{array}{l}4.6 \\
4.4\end{array}$ & $\begin{array}{l}3.1+4 \\
3.4\end{array}$ & $\begin{array}{l}B .5 \\
3.0\end{array}$ & $\begin{array}{l}7.9 \\
8.3\end{array}$ & $\begin{array}{l}3.8 \\
4.0\end{array}$ & $\begin{array}{l}2.8 \\
2.6\end{array}$ & $\begin{array}{l}3.5 \\
3.3\end{array}$ & $\begin{array}{l}5.6 \\
5.7\end{array}$ & $\begin{array}{l}4.6 \\
4.3\end{array}$ & $\begin{array}{l}3.5 \\
3.6\end{array}$ & $\begin{array}{l}4.9 \\
4.8\end{array}$ & $\begin{array}{l}7.2 \\
6.0\end{array}$ \\
\hline$Y$ & 3.5 & 3.9 & 4.1 & 3.9 & 7.9 & 9.3 & 3.5 & 3.9 & 3.3 & 6.0 & 4.0 & 4.1 & 4.6 & 5.7 \\
\hline
\end{tabular}


per metal ion, has been observed to exceed 3.0 at the higher ligand concentrations in some of the rare-earth alphahydroxycarboxylate complexes.

The average values of $b_{1} / b_{2}$ equal to $3.8 \pm 0.7$ and of $b_{2} / b_{3}$ equal to $3.5 \pm 0.5$ for the not too highly substituted glycolates are in close agreement with the values expected for several eight-coordinate configurations such as the cubic, Archimedean antiprism, dodecahedral, and a trigonal prism in which two extra orbitals extend from the triangular faces of the prism. The values of the ratios expected for each of these configurations are given in Table 7 .

Due to appreclable variations in the individual $b_{1} / b_{2}$ and $b_{2} / b_{3}$ values obtained, and the inability to calculate $b_{3} / b_{4}$ ratios from the dilute solution data, it was not

Table 7. Statistical factors in the ratios of the stepwise formation constants for various eight-coordinate configurations

Configuration $b_{1}: b_{2}: b_{3}: b_{4} \quad b_{1} / b_{2} b_{2} / b_{3} b_{3} / b_{4}$

Cubic

$12 / 1: 7 / 2: 22 / 21: 9 / 44$

$3.43 \quad 3.34 \quad 5.12$

Archimedean

antiprism

$16 / 1: 9 / 2: 11 / 9: 7 / 44$

$3.56 \quad 3.68 \quad 7.68$

Dodecahedral

$18 / 1: 89 / 18: 118 / 89: 24 / 157$

$3.64 \quad 3.73 \quad 8.67$

Trigonal prism

with ends

$15 / 1: 21 / 5: 10 / 9: 6 / 35$

$\begin{array}{lll}3.57 & 3.78 & 6.48\end{array}$ 
possible to assign any exact conflgurations to any of the complexes, but the configuration may correspond to the eight coordinate dodecahedral conflguration assigned to the hydrated heavy-rare earth EDTA chelates on the basis of X-ray data (79). Such a conflguration has also been proposed for the europium benzoylacetone and dibenzoylmethide chelates $(80)$.

other factors also act to prevent accurate predictions of geometrical configurations of complexes from stability constant data. The ratios derived from statistical considerations based on the assumption of point ligands cannot be expected to be the same when bulky organic groups are involved. Furthermore, in calculating these ratios, it was assumed that the alpha-hydroxycarboxylate ligand attaches itself bidentately to the metal ion. If the carboxyl group acts as a bidentate group for any of the metals, this will be a further contribution to deviation of the actual ratios from the theoret1cal values. Hence it must bo concluded that the chief value of the ratios of the sucessslve $b$ values lies in indicating the amount of steric hindrance encountered as each successive ligand attaches itself to the metal ion. 


\section{SUMMARY}

The formation constants of the rare earths with the isopropylglycolate, methylisopropylglycolate, tertiarybutylglycolate, and methyltertiarybuthlglycolate ligands were determined. The magnitudes of these constants were found to follow the ionic radius trend quite regularly. Introduction of a methyl group into a ligand gave enhanced stabilities to the complexes, especially for the heavier rare earths, over the analogous homologue with a hydrogen atom instead of a methyl group. Introduction of a bulkier alkyl group decreased stability of the complex. 
VI. BIBLIOGRAPHY

1. Hughes, D. J. and Harvey, J.A., U. S. Atomic Energy Commission Report BNL-325 [Brookhāveñ National Lab., Upton, N. Y.J (1955).

2. Ketelle, B. H. and Boyd, G. E., I. Am. Chem. Soc., 69, 2800 (1947).

3. McCoy; H., J. Am. Chem. Soc., 57, 1756 (1935).

4. Healy, R. M. and Kremers, H. E., "Separation of Rare Earths by Fractional Crystallization," in Spedding, F. H. and Daane, A. H., eds., "The Rare Earths," pp. 29-37, John Wiley and Sons, Inc., New York (1961).

5. Spedding, F. H., Fulmer, E. I., Butler, T. A., and Powell, J. E., J. Am. Chem. Soc., 22, 2349 (1950).

6. Spedding, F. H., Fulmer, E. I., Powell, J. E., and Butler, T. A., J. Am. Chem. Soc., 22, 2354 (1950).

7. Spedding, F. H., Fulmer, E. I., Powell, J. E., Butler, T.A.; and Yaffe, T. S., I. Am. Chem. Soc., 73,4840 (1951).

8. Spedding, F. H. and Powell, J. E., J. Am. Chem. Soc., 26, 2545 (1954).

9. Spedding, F. H. and Powell, J. E., Chem. Eng. Prog. Symp. Series, 50, No. 14, 7 (1954).

10. Spedding, F. H. and Powell, J. E., Amer. Inst. Min. (Metal1.) Engrs. Trans., 200, 1131 (1954).

11. Powell, J. E., "The Separation of Rare Earths by Ion Exchange," in Eyring, L., ed., "Science and Technology of the Rare Earths," pp. 62-82, The Macmillan Company, New York (1964).

12. Powell, J. E. and Spedding, F. H., U. S. Atomic Energy Commission Report ISC-617 [Ames Lab., Ámes, Iowa] (1960).

13. Powell, J. E. and Spedding, F. H., Chem. Eng. Progr. Symp. Series, 52 , No. 24,101 (1959). 
14. Peppard, D. F., J. Phys. Chem., 27, 294 (1953).

15. Weaver, B., Kappelmann, F. A., and Topp, A. C., J. Am. Chem. Soc., 25, 3943 (1953).

16. Peppard, D. F., "Fractionation of Rare Earths by LiquidLiquid Extraction Using Phosphorus - Based Extractants," in Eyring, L. ed. "Science and Technology of the Rare Earths," pp. 89-108, The Macmillan Company, New York $(1964)$.

17. Sonesson, A., Acta Chem. Scand., 13, 1437 (1959).

18. Sonesson, A., Acta Chem. Scand., 14, 1495 (1960).

19. Sonesson, A., Acta Chem. Scand., 13, 998 (1959).

20. Karraker, R. H., "Stability Constants of Some RareEarth-Metal Chelates", unpublished Ph.D. thesis, Library, Iowa State University of Science and Technology, Ames, Iowa (1961).

21. Kolat, R. S., "A Study of the Rare-Earth Metal Complexes", unpublished Ph.D. thesis, Library, Iowa State University of Science and Technology, Ames, Iowa (1961).

22. Deelstra, H., Vanderleen, W., and Verbeek, F., Bull. Soc. Chim. Belges, 22, 632 (1963). 23. Stagg, W. R. and Powell, J. E., Inorg. Chem., 3, 242
(1964).

24. Choppin, G. R. and Chopoorian, J. A., I. Inorg. Nucl. Chem., 22, 97 (1962).

25. Fleischer, D., "Stability Constants of Some Lanthanide Aliphatic Alpha-Hydroxycarboxylates, "unpubI ished M. S. thesis, Library, Iowa State University of Sclence and Technology, Ames, Iowa (1965).

26. Powell, J. E., Paul, G. S., Fleischer, D., Stagg, W. R., and Suzuki, $Y_{.}, U$. S. Atomic Energy Commission Report IS-900 [Iowa State University of Science and Technology, Ames. Inst. for Atomic Research] (1964).

27. Eeckhaut, L., Verbeek, F., Deelstra, H., and Hoste, J., Anal. Chim. Acta, 30,369'(1964). 
28. Sok, B. A., "Some Properties of Rare-Earth 1-Hydroxycycloalkane Carboxylic Acid Complexes," unpublished M.S. thesis, Library, Iowa State University of Science and Technology, Ames, Iowa (1965).

29. Nervick, W. E., J. Phys. Chem., 52, 690 (1955).

30. Mayer, S. W. and Freiling, E. C., I. Am. Chem. Soc., 25, 5647 (1953).

31. Wish, L., Freiling, E. C., and Bunney, L. R., I. Am. Chem. Soc., 76, 3444 (1954).

32. Smith, H. L. and Hof fman, D. C., J. Inorg. Nucl. Chem., $3,243(1956)$.

33. Maslova, G. B., Nazavov, P. P., and Chmutov, K. V., Zhur. Neorg. Chim., 5, 359 (1960).

34. Stewart, D. C., J. Inorg. Nucl. Chem., 4, 131 (1957).

35. Freiling, E. C. and Bunney, L. R., I. Am. Chem. Soc., 26, 1021 (1954).

36. Cunninghame, J. G., Sizeland, M. L., Willis, H. H., Eakins, J., and Merocr, E. R., J. Inurg. NuCl. Chem., I, $163^{\prime}(1955)$.

37. Stewart, D. C., Anal. Chem., 27, 1279 (1955).

38. Chuppin, G. K., Harvey, B. G., and Thompson, S. G., I. Inorg. Nucl. Chem., 2, 66 (1956).

39. Sonesson, A., Acta Chem. Scand., 12, 165 (1958).

40. Sonesson, A., Acta Chem. Scand., 12, 1937 (1958).

41. Stagg, W. R. and Powell, J. E., U. S. Atomic Energy Commission Report IS-727 [Iowa state University of Science and Technology, Ames, Iowa. Inst. for Atomic Research] (1963).

42. Moeller, T., J. Phys. Chem., 50, 242 (1946).

43. Biedermann, G. and Clavatta, L., Acta Chem. Scand., 15, 1347 (1961). 
44. Bjerrum, J., "Metal Ammine Formation in Aqueous Solution," P. Haase and Son, Copenhagen, Denmark (1941).

45. Rossotti, F. J. C. and Rossotti, H., "The Determination of Stability Constants," McGraw-Hili Book Co., Inc., New York (1962).

46. Fronaeus, S., "Komplexsystem Hos Koppar," unpublished Ph.D. thesis, Library, University of Lund, Lund, Sweden (1948).

47. Bjerrum, J., "Metal Ammine Formation in Aqueous Solution," unpublished Ph.D. thesis, Library, University of Copenhagen, Copenhagen, Denmark (1941).

48. Leden, I., "Potentiometrisk Undersokning Av Nagra Cadmiumsalters Komplexitet," unpublished Ph.D. thesis, Library, University of Lund, Lund, Sweden (1948).

49. Sullivan, J. C., Rydberg, J., and Miller, W. F., Acta Chem. Scand., 13, 2033 (1959).

50. Rydberg, J., Acta Chem. Scand., 14, 157 (1960).

51. Walton, H. F., "Elementary Quantitative Analysis," Prentice-Hall, Inc., Englewood Cliffs, New Jersey (1958).

52. Powell, J. E. and Hiller, M. A., J. Chem. Ed., 34, 330 (1957).

53. Choppin, G. R. and Dinius, R. H., Inorg. Chem., I, 140 (1962).

54. Larkins, T. H. and Jones, M. M., Inorg. Chem., 2, 1391 (1963).

55. Jones, M. M., Jones, E. A., Harmon, D. F., and Summer, R. J., J. Am. Chem. Soc., 83, 2038 (1961).

56. Atkinson, G. and Bauman, J. E., Inorg. Chem., 1, 900 (1962).

57. Moeller, T., Thompson, L. C. and Ferrus, R., "Some Aspects of the Stabilities of Amine Polycarboxylic Acid Chelates of the Tripositive Rare Earth Metal Ions," in Kleber, E. V., ed., "Rare Earth Research," pp. 3-10, The Macmilian Company, New York (1961). 
58. Grenthe, I., I. Am. Chem. Soc., 83, 360 (1961).

59. Thompson, L. C., Inorg. Chem., 1, 490 (1962).

60. Thompson, L. C., Inorg. Chem., 3, 1319 (1964).

61. Powell, J. E., Kolat, R. S., and Paul, G. S., Inorg. Chem., 3, 518 (1964).

62. Schwarzenbach, G., Gut R., and Anderegg, G., Helv. Chim. Acta, 37, 937 (1954). 63. Powell, J. E, and Mackey, J. L., Inorg. Chem., I,
$418(1962)$.

64. Levy, S. C. and Powell, J. E., U. S. Atomic Energy Commission Report IS-421 [Iowa State Iniversity of Science and Technology, Ames. Inst. for Atomic Research] (1961).

65. Moeller, T. and Brantley, J. C., I. Am. Chem. Soc., Z2, 5447 (1950).

66. Moeller, T. and Ulrich, W. F., J. Inorg. Nucl. Chem., 2, 164 (1956).

67. Holleck, L. and Eckhardt, D., Z. Naturforsch., 吕, 660 (1953).

68. Holleck, L. and Eckharat, D., Z. Naturforsch., 9a,

69. Holleck, L. and Eckhardt, D., Z. Naturforsch., 2b, 274 (1954),

70. Vlekery, R. C., J. Mol. Spectroscopy, 2, 308 (1958).

71. Holleck, L. and Liebold, 0., Naturwissenschaften, 44, 583 (1957).

72. Moeller, 'T. and Horwitz, E. P., J. Inorg. Nucl. Chem., 12,49 (1959).

73. Harder, R. and Chaberek, S., J. Inorg. Nucl. Chem., 11, 197 (1959).

74. George, P., McClure, D. S., Griffith, J. S., and Orgel, L. E., I. Chem. Phys., 24, 1269 (I956). 
75. Stavely, L. A. K. and Randall, T., Discussions Faraday Soc., №. 26, 157 (1958).

76. Kolat, R. S. and Powell, J. E., Inorg. Chem., I, 293 (1962).

77. Wells, A. F., "Structural Inorganic Chemistry." Oxford University Press, London (1962).

78. Cotton, F. A. and Wilkinson, G.., "Advanced Inorganic Chemistry." John Wiley and Sons, Inc., New York (1962).

79. Hoard, J. L., Lind, M. D., and Lee, Byung-Kook, "Stereochemistry of the Ethylenediaminetetraacetato Complexes of Lanthanum and Other Rare Earth (III) Ions." Presented to the Fourth Rare Earth Research Conference, Phoenix, Arizona (1964).

- 80. Brecher, C., Lempicki, A., and Samuelson, H., J. Chem. Phys., 41, 279 (1964). 
VII. APPENDIX A: EXPERIMENTAL DATA FOR DETERMINATION OF IONIZATION CONSTANTS OF THE LIGAND ACIDS

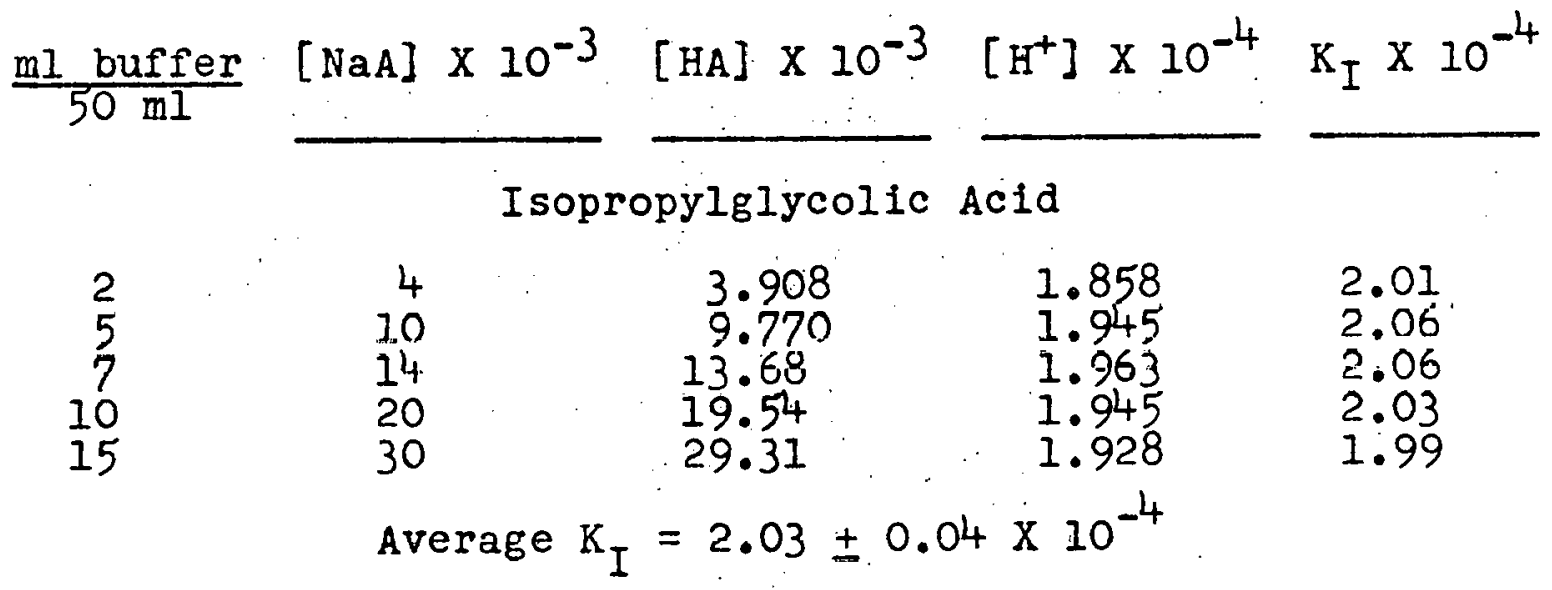

Methylisopropylglycolic Acid

$\begin{array}{rrrrr}2 & 4 & 3.969 & 1.611 & 1.76 \\ 5 & 10 & 9.923 & 1.683 & 1.76 \\ 7 & 14 & 13.89 & 1.687 & 1.74 \\ 10 & 20 & 19.85 & 1.690 & 1.73 \\ 15 & 30 & 29.77 & 1.652 & 1.68 \\ 20 & 40 & 39.69 & 1.629 & 1.66 \\ & \text { Average } K_{I}=1.71 \pm 0.05 \times 10^{-4} & \end{array}$

Tertiarybutylglycolic Acid

$\begin{array}{rrrrr}2 & 4 & 3.952 & 1.276 & 1.38 \\ 5 & 10 & 9.880 & 1.303 & 1.35 \\ 7 & 14 & 13.83 & 1.306 & 1.35 \\ 10 & 20 & 19.76 & 1.297 & 1.33 \\ 15 & 30 & 29.64 & 1.279 & 1.31 \\ & & & \end{array}$




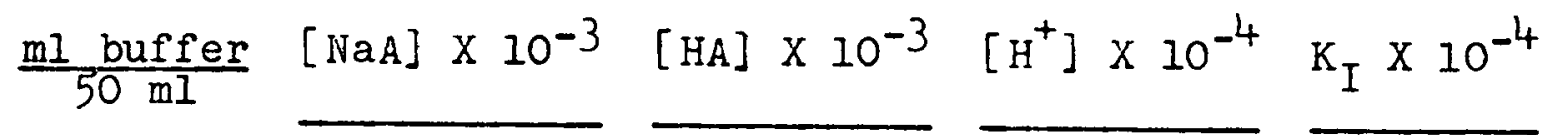

Methyltertiarybutylglycolic Acid

8
10
12
14
16
18
20

8
10
12
14
16
18
20

4.256

5.320

6.384

7.448

8.512

9.576

Average $K_{I}=1.14 \pm 0.01 \times 10^{-4}$
5.998

5.970

5.998

5.970

5.998

5.943

5.929

1.15

1.14

1.14

1.14

1.14

1.13 
VIII. APPENDIX B: EXPERIMENTAL DATA FOR THE RARE-EARTH ISOPROPYIGLYCOLATES

\begin{tabular}{|c|c|c|c|c|c|c|c|}
\hline 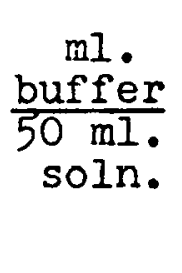 & $\mathrm{La}$ & +3 & $\operatorname{ax} 10^{-3}$ & 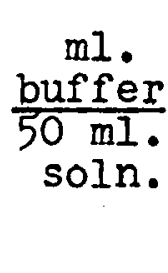 & $\mathrm{pH}$ & +3 & $a \times 10^{-3}$ \\
\hline $\begin{array}{l}0.50 \\
1.00\end{array}$ & $\begin{array}{l}3.686 \\
3.614\end{array}$ & $\begin{array}{l}0.112 \\
0.204\end{array}$ & $\begin{array}{l}0.758 \\
1.426\end{array}$ & $\begin{array}{l}0.50 \\
1.00\end{array}$ & $\begin{array}{l}3 \cdot 590 \\
3 \cdot 545\end{array}$ & $\begin{array}{l}0.126 \\
0.230\end{array}$ & $\begin{array}{l}0.650 \\
1.261\end{array}$ \\
\hline $\begin{array}{l}1.50 \\
2.50\end{array}$ & $\begin{array}{l}3.589 \\
3.569\end{array}$ & $\begin{array}{l}0.288 \\
0.450\end{array}$ & $\begin{array}{l}2.104 \\
3.469\end{array}$ & $\begin{array}{l}1.50 \\
2.50\end{array}$ & $\begin{array}{l}3 \cdot 526 \\
3 \cdot 520\end{array}$ & $\begin{array}{l}0.333 \\
0.513\end{array}$ & $\begin{array}{l}1.863 \\
3.147\end{array}$ \\
\hline $\begin{array}{l}3.50 \\
5.00\end{array}$ & $\begin{array}{l}3.571 \\
3.572\end{array}$ & $\begin{array}{l}0.577 \\
0.769\end{array}$ & $\begin{array}{l}4.962 \\
7.193\end{array}$ & $\begin{array}{l}3.50 \\
5.00\end{array}$ & $\begin{array}{l}3.528 \\
3.538\end{array}$ & $\begin{array}{l}0.662 \\
0.869\end{array}$ & $\begin{array}{l}4.546 \\
6.709\end{array}$ \\
\hline $\begin{array}{l}6.20 \\
7.50\end{array}$ & $\begin{array}{l}3.577 \\
3.582\end{array}$ & $\begin{array}{l}0.898 \\
1.028\end{array}$ & $\begin{array}{r}9.071 \\
11.15\end{array}$ & $\begin{array}{l}6.20 \\
7.50\end{array}$ & $\begin{array}{l}3.548 \\
3.556\end{array}$ & $\begin{array}{l}1.007 \\
1.153\end{array}$ & $\begin{array}{r}8.550 \\
10.56\end{array}$ \\
\hline $\begin{array}{l}10.00 \\
12.50\end{array}$ & $\begin{array}{l}3.596 \\
3: 603\end{array}$ & $\begin{array}{l}1.206 \\
1.400\end{array}$ & $\begin{array}{l}15.43 \\
19.65\end{array}$ & $\begin{array}{l}10.00 \\
12.50\end{array}$ & $\begin{array}{l}3.577 \\
3.589\end{array}$ & $\begin{array}{l}1.331 \\
1 \cdot 512\end{array}$ & $\begin{array}{l}14.84 \\
19.11\end{array}$ \\
\hline 15.00 & 3.612 & 1.529 & 24.13 & $\begin{array}{l}15.00 \\
20.00\end{array}$ & $\begin{array}{l}3.600 \\
3.623\end{array}$ & $\begin{array}{l}1.651 \\
1.744\end{array}$ & $\begin{array}{l}23.54 \\
33.16\end{array}$ \\
\hline \multicolumn{4}{|c|}{$\mathrm{Pr}^{+3}$} & \multicolumn{4}{|c|}{$\mathrm{Nd}^{+} 3$} \\
\hline $\begin{array}{l}0.50 \\
1.00\end{array}$ & $\begin{array}{l}3.628 \\
3.554\end{array}$ & $\begin{array}{l}0.149 \\
0.266\end{array}$ & $\begin{array}{l}0.638 \\
1.216\end{array}$ & $\begin{array}{l}0.50 \\
1.00\end{array}$ & $\begin{array}{l}3.614 \\
3.536\end{array}$ & $\begin{array}{l}0.158 \\
0.283\end{array}$ & $\begin{array}{l}0.612 \\
1.158\end{array}$ \\
\hline $\begin{array}{l}1.50 \\
2.50\end{array}$ & $\begin{array}{l}3.528 \\
3.514\end{array}$ & $\begin{array}{l}0.37 !_{+} \\
0.568\end{array}$ & $\begin{array}{l}1.802 \\
3.032\end{array}$ & $\begin{array}{l}1 \cdot 50 \\
2 \cdot 50\end{array}$ & $\begin{array}{l}3.510 \\
3.499\end{array}$ & $\begin{array}{l}0.397 \\
0.597\end{array}$ & $\begin{array}{l}1.721 \\
.2 .930\end{array}$ \\
\hline $\begin{array}{l}3.50 \\
5.00\end{array}$ & $\begin{array}{l}3.518 \\
3.530\end{array}$ & $\begin{array}{l}0.734 \\
0.946\end{array}$ & $\begin{array}{l}4.368 \\
6.511\end{array}$ & $\begin{array}{l}3.50 \\
5.00\end{array}$ & $\begin{array}{l}3.506 \\
3.519\end{array}$ & $\begin{array}{l}0.767 \\
0.990\end{array}$ & $\begin{array}{l}4.244 \\
6.342\end{array}$ \\
\hline $\begin{array}{l}6.20 \\
7.50\end{array}$ & $\begin{array}{l}3 \cdot 538 \\
3 \cdot 548\end{array}$ & $\begin{array}{l}1.103 \\
1.247\end{array}$ & $\begin{array}{c}8.277 \\
10.29\end{array}$ & $\begin{array}{l}62.0 \\
7.50\end{array}$ & $\begin{array}{l}3.530 \\
3.544\end{array}$ & $\begin{array}{l}1.143 \\
1.273\end{array}$ & $\begin{array}{c}8.122 \\
10.20\end{array}$ \\
\hline $\begin{array}{l}10.00 \\
12.50\end{array}$ & $\begin{array}{l}3.568 \\
3.584\end{array}$ & $\begin{array}{l}1.455 \\
1.614\end{array}$ & $\begin{array}{l}14.45 \\
18.80\end{array}$ & $\begin{array}{l}10.00 \\
12.50\end{array}$ & $\begin{array}{l}3 \cdot 567 \\
3.580\end{array}$ & $\begin{array}{l}1.463 \\
1.658\end{array}$ & $\begin{array}{l}14.42 \\
18.63\end{array}$ \\
\hline $\begin{array}{l}15.00 \\
20.00\end{array}$ & $\begin{array}{l}3.598 \\
3.618\end{array}$ & $\begin{array}{l}1.724 \\
1.890\end{array}$ & $\begin{array}{l}23.36 \\
32.68\end{array}$ & $\begin{array}{l}15.00 \\
20.00\end{array}$ & $\begin{array}{l}3.593 \\
3.518\end{array}$ & $\begin{array}{l}1.794 \\
1.890\end{array}$ & $\begin{array}{l}23.08 \\
32.68\end{array}$ \\
\hline
\end{tabular}




$$
\mathrm{Sm}^{+3}
$$

$\begin{array}{llll}0.50 & 3.568 & 0.185 & 0.530 \\ 1.00 & 3.485 & 0.330 & 1.008\end{array}$

$\begin{array}{llll}1.50 & 3.459 & 0.460 & 1.507\end{array}$

$\begin{array}{llll}1.50 & 3.450 & 0.691 & 2.589\end{array}$

$\begin{array}{llll}3.50 & 3.459 & 0.890 & 3.788 \\ 5.00 & 3.478 & 1.145 & 5.752\end{array}$

$\begin{array}{llll}6.20 & 3.499 & 1.292 & 7.547 \\ 7.50 & 3.512 & 1.462 & 9.459\end{array}$

$\begin{array}{llll}10.00 & 3.543 & 1.663 & 13.63 \\ 12.50 & 3.561 & 1.863 & 17.82\end{array}$

$\begin{array}{llll}15.00 & 3.577 & 2.007 & 22.24\end{array}$ $\begin{array}{llll}120.00 & 3.605 & 2.133 & 31.71\end{array}$

$$
\mathrm{Gd}^{+3}
$$

$\begin{array}{llll}0.50 & 3.548 & 0.197 & 0.497 \\ 1.00 & 3.464 & 0.348 & 0.950\end{array}$

$\begin{array}{llll}1.50 & 3.433 & 0.490 & 1.408\end{array}$

$\begin{array}{llll}1.50 & 3.4 .26 & 0.734 & 2.439\end{array}$

$\begin{array}{llll}3.50 & 3.435 & 0.249 & 3.573 \\ 5.00 & 3.460 & 1.209 & 5.512\end{array}$

$\begin{array}{llll}6.20 & 3.480 & 1.379 & 7.217 \\ 7.50 & 3.496 & 1.553 & 9.108\end{array}$

10.00

12.50

$$
\begin{array}{lll}
3.527 & 1.792 & 13.13
\end{array}
$$

15.00 20.00
0.50

1.00

3.553
3.465

0.194

0.347

0.505

$\begin{array}{llll}1.50 & 3.436 & 0.487 & 1.419 \\ 2.50 & 3.429 & 0.729 & 2.457\end{array}$

$\begin{array}{llll}3.50 & 3.438 & 0.942 & 3.599 \\ 5.00 & 3.460 & 1.209 & 5.512\end{array}$

$\begin{array}{llll}6.20 & 3.477 & 1.392 & 7.166 \\ 7.50 & 3.491 & 1.581 & 9.001\end{array}$

$\begin{array}{llll}10.00 & 3.525 & 1.807 & 13.07\end{array}$

$\begin{array}{llll}15.00 & 3.561 & 2.212 & 21.43\end{array}$ $\begin{array}{llll}20.00 & 3.592 & 2.372 & 30.77\end{array}$

$$
\mathrm{Tb}^{+3}
$$

$\begin{array}{llll}0.50 & 3.571 & 0.214 & 0.449 \\ 1.00 & 3.431 & 0.376 & 0.866\end{array}$

$\begin{array}{llll}1.50 & 3.309 & 0.529 & 1.283 \\ 2.50 & 3.390 & 0.795 & 2.229\end{array}$

$\begin{array}{llll}3.50 & 3.402 & 1.025 & 3.297 \\ 5.00 & 3.430 & 1.310 & 5.130\end{array}$

$\begin{array}{llll}6.20 & 3.453 & 1.496 & 6.769 \\ 7.50 & 3.475 & 1.667 & 8.668\end{array}$

$\begin{array}{llll}10.00 & 3.510 & 1.922 & 12.62\end{array}$

$\begin{array}{llll}12.50 & 3.538 & 2.099 & 16.89\end{array}$

$\begin{array}{llll}15.00 & 3.559 & 2.238 & 21.32 \\ 20.00 & 3.592 & 2.372 & 30.77\end{array}$ 


$$
\mathrm{Dy}^{+3}
$$

$\begin{array}{llll}0.50 & 3.492 & 0.227 & 0.412 \\ 1.00 & 3.403 & 0.399 & 0.799\end{array}$

$\begin{array}{llll}1.50 & 3.367 & 0.562 & 1.181 \\ 2.50 & 3.360 & 0.842 & 2.067\end{array}$

$\begin{array}{llll}3.50 & 3.377 & 1.080 & 3.101 \\ 5.00 & 3.410 & 1.375 & 4.890\end{array}$

$\begin{array}{llll}6.20 & 3.435 & 1.570 & 6.486 \\ 7.50 & 3.457 & 1.760 & 8.310\end{array}$

$\begin{array}{llll}10.00 & 3.498 & 2.012 & 12.27\end{array}$

$\begin{array}{llll}12.50 & 3.523 & 2.247 & 16.31\end{array}$

$\begin{array}{llll}15.00 & 3.547 & 2.386 & 20.74\end{array}$ $\begin{array}{llll}15.00 & 3.547 & 2.386 & 20.74 \\ 20.00 & 3.583 & 2.531 & 30.14\end{array}$

$$
\operatorname{Er}^{+3}
$$

0.50

1.00

$$
3.464
$$

0.242

0.374
0.707

$\begin{array}{llll}1.50 & 3.333 & 0.597 & 1.077 \\ 2.50 & 3.327 & 0.893 & 1.900\end{array}$

$\begin{array}{llll}3.50 & 3.345 & 1.146 & 2.866 \\ 5.00 & 3.380 & 1.167 & 4.549\end{array}$

$\begin{array}{llll}6.20 & 3.411 & 1.6666 & 5.126 \\ 7.50 & 3.438 & 1.855 & 7.944\end{array}$

$\begin{array}{llll}10.00 & 3.485 & 2.106 & 11.90\end{array}$

12.50

$\begin{array}{llll}15.00 & 3.541 & 2.458 & 20.46\end{array}$

$20.00 \quad 3.574 \quad 2.689 \quad 29.51$
0.50

1.00

3.483

0.232

0.399

$\begin{array}{llll}1.50 & 3.355 & 0.575 & 1.143 \\ 2.50 & 3.350 & 0.858 & 2.015\end{array}$

$\begin{array}{llll}3.50 & 3.368 & 1.099 & 3.033 \\ 5.00 & 3.399 & 1.409 & 4.763\end{array}$

$\begin{array}{llll}6.20 & 3.428 & 1.598 & 6.380\end{array}$

$7.50 \quad 3.450 \quad 1.795 \quad 8.173$

$\begin{array}{llll}10.00 & 3.495 & 2.034 & 12.18\end{array}$

$\begin{array}{llll}12.50 & 3.525 & 2.227 & 16.39\end{array}$

$\begin{array}{llll}15.00 & 3.547 & 2.386 & 20.74 \\ 20.00 & 3.586 & 2.4 .78 & 30.35\end{array}$

$$
\mathrm{Tm}^{+3}
$$

$\begin{array}{llll}0.50 & 3.444 & 0.253 & 0.348 \\ 1.00 & 3.344 & 0.445 & 0.672\end{array}$

$\begin{array}{llll}1.50 & 3.310 & 0.620 & 1.011 \\ 2.50 & 3.305 & 0.925 & 1.796\end{array}$

$\begin{array}{llll}3.50 & 3.326 & 1.184 & 2.735 \\ 5.00 & 3.364 & 1.514 & 1.378\end{array}$

$\begin{array}{llll}6.20 & 3.396 & 1.723 & 5.911 \\ 7.50 & 3.427 & 1.808 & 7.741\end{array}$

$\begin{array}{llll}10.00 & 3.475 & 2.177 & 11.63 \\ 12.50 & 3.508 & 2.390 & 15.75\end{array}$

$\begin{array}{llll}15.00 & 3.535 & 2.530 & 20.17 \\ 20.00 & 3.573 & 2.705 & 29.45\end{array}$ 
$\mathrm{Yb}^{+3}$

$\begin{array}{llllllll}0.50 & 3.423 & 0.264 & 0.322 & 0.50 & 3.410 & 0.271 & 0.306 \\ 1.00 & 3.317 & 0.466 & 0.619 & 1.00 & 3.305 & 0.475 & 0.597 \\ 1.50 & 3.280 & 0.649 & 0.930 & 1.50 & 3.268 & 0.660 & 0.899 \\ 2.50 & 3.277 & 0.964 & 1.671 & 2.50 & 3.264 & 0.982 & 1.616 \\ 3.50 & 3.299 & 1.236 & 2.558 & 3.50 & 3.290 & 1.253 & 2.501 \\ 5.00 & 3.341 & 1.579 & 4.142 & 5.00 & 3.336 & 1.592 & 4.092 \\ 6.20 & 3.378 & 1.789 & 5.663 & 6.20 & 3.373 & 1.807 & 5.597 \\ 7.50 & 3.409 & 1.993 & 7.419 & 7.50 & 3.406 & 2.006 & 7.367 \\ 10.00 & 3.462 & 2.266 & 11.28 & 10.00 & 3.460 & 2.280 & 11.23 \\ 12.50 & 3.498 & 2.482 & 15.39 & 12.50 & 3.495 & 2.510 & 15.28 \\ 15.00 & 3.525 & 3.647 & 19.71 & 15.00 & 3.525 & 2.647 & 19.71 \\ 20.00 & 3.566 & 2.824 & 28.98 & 20.00 & 3.564 & 2.859 & 28.84\end{array}$

$\mathrm{Lu}^{+3}$
$\mathrm{Y}^{+3}$

$\begin{array}{llll}0.50 & 3.512 & 0.217 & 0.441\end{array}$ $\begin{array}{llll}1.00 & 3.423 & 0.383 & 0.846\end{array}$

$\begin{array}{llll}1.50 & 3.393 & 0.535 & 1.266 \\ 2.50 & 3.385 & 0.803 & 2.201\end{array}$

$\begin{array}{llll}3.50 & 3.400 & 1.029 & 3.281 \\ 5.00 & 3.427 & 1.320 & 5.093\end{array}$

$\begin{array}{llll}6.20 & 3.452 & 1.500 & 6.753 \\ 7.50 & 3.472 & 1.682 & 8.608\end{array}$

$\begin{array}{llll}10.00 & 3.510 & 1.922 & 12.62 \\ 12.50 & 3.536 & 2.120 & 16.81\end{array}$

$\begin{array}{llll}15.00 & 3.559 & 2.238 & 21.32 \\ 20.00 & 3.594 & 2.336 & 30.01\end{array}$ 
IX. APPENDIX C: EXPERIMENTAL DATA FOR THE RARE-EARTH METHYLISOPROPYIGLYCOLATES

\begin{tabular}{|c|c|c|c|c|c|c|c|}
\hline $\begin{array}{c}\text { ml. } \\
\frac{\text { buffer }}{50 \mathrm{ml} .} \\
\text { soln. }\end{array}$ & $\mathrm{La}$ & $\bar{n}$ & $a \times 10^{-3}$ & $\frac{\begin{array}{c}\text { ml. } \\
\text { buffer }\end{array}}{\text { soln. }}$ & $\mathrm{pH}$ & $\bar{n}$ & $\mathrm{ax} 10^{-3}$ \\
\hline $\begin{array}{l}0.50 \\
1.00\end{array}$ & $\begin{array}{l}3.7^{4}+9 \\
3.685\end{array}$ & $\begin{array}{l}0.099 \\
0.184\end{array}$ & $\begin{array}{l}0.781 \\
1.472\end{array}$ & $\begin{array}{l}0.50 \\
1.00\end{array}$ & $\begin{array}{l}3.676 \\
3.628\end{array}$ & $\begin{array}{l}0.097 \\
0.196\end{array}$ & $\begin{array}{l}0.718 \\
1.346\end{array}$ \\
\hline $\begin{array}{l}1.50 \\
2.50\end{array}$ & $\begin{array}{l}3.656 \\
3.644\end{array}$ & $\begin{array}{l}0.272 \\
0.415\end{array}$ & $\begin{array}{l}2.134 \\
3.567\end{array}$ & $\begin{array}{l}1.50 \\
2.50\end{array}$ & $\begin{array}{l}3.610 \\
3.604\end{array}$ & $\begin{array}{l}0.292 \\
0.459\end{array}$ & $\begin{array}{l}1.975 \\
3.309\end{array}$ \\
\hline $\begin{array}{l}3.50 \\
5.00\end{array}$ & $\begin{array}{l}3.644 \\
3.644\end{array}$ & $\begin{array}{l}0.541 \\
0.731\end{array}$ & $\begin{array}{l}5.062 \\
7.304\end{array}$ & $\begin{array}{l}3.50 \\
5.00\end{array}$ & $\begin{array}{l}3.608 \\
3.618\end{array}$ & $\begin{array}{l}0.606 \\
0.798\end{array}$ & $\begin{array}{l}4.718 \\
6.944\end{array}$ \\
\hline $\begin{array}{l}6.20 \\
7.50\end{array}$ & $\begin{array}{l}3.653 \\
3.656\end{array}$ & $\begin{array}{l}0.832 \\
0.966\end{array}$ & $\begin{array}{l}9.294 \\
11.36\end{array}$ & $\begin{array}{l}6.20 \\
7.50\end{array}$ & $\begin{array}{l}3.625 \\
3.633\end{array}$ & $\begin{array}{l}0.939 \\
1.072\end{array}$ & $\begin{array}{l}8.778 \\
10.84\end{array}$ \\
\hline $\begin{array}{l}10.00 \\
12.50\end{array}$ & $\begin{array}{l}3.668 \\
3.675\end{array}$ & $\begin{array}{l}1.147 \\
1.329\end{array}$ & $\begin{array}{l}15.63 \\
19.90\end{array}$ & $\begin{array}{l}10.00 \\
12.50\end{array}$ & $\begin{array}{l}3.649 \\
3.661\end{array}$ & $\begin{array}{l}1.272 \\
1.443\end{array}$ & $\begin{array}{l}15.03 \\
19.34\end{array}$ \\
\hline $\begin{array}{l}15.00 \\
20.00\end{array}$ & $\begin{array}{l}3.68 ! 1 \\
3.700\end{array}$ & $\begin{array}{l}1.447 \\
1.587\end{array}$ & $\begin{array}{l}24.42 \\
33.85\end{array}$ & $\begin{array}{l}15.00 \\
20.00\end{array}$ & $\begin{array}{l}3.670 \\
3.692\end{array}$ & $\begin{array}{l}1.547 \\
1.695\end{array}$ & $\begin{array}{l}23.72 \\
33.32\end{array}$ \\
\hline \multicolumn{4}{|c|}{$\mathrm{Fr}^{+} 3$} & \multicolumn{4}{|c|}{$\mathrm{Nd}^{+3}$} \\
\hline $\begin{array}{l}0.50 \\
1.00\end{array}$ & $\begin{array}{l}3.701 \\
3.624\end{array}$ & $\begin{array}{l}0.129 \\
0.245\end{array}$ & $\begin{array}{l}0.681 \\
1.257\end{array}$ & $\begin{array}{l}0.50 \\
1.00\end{array}$ & $\begin{array}{l}3.668 \\
3.597\end{array}$ & $\begin{array}{l}0.149 \\
0.271\end{array}$ & $\begin{array}{l}0.619 \\
1.171\end{array}$ \\
\hline $\begin{array}{l}1.50 \\
2.50\end{array}$ & $\begin{array}{l}3.594 \\
3.584\end{array}$ & $\begin{array}{l}0.357 \\
0.544\end{array}$ & $\begin{array}{l}1.828 \\
3.085\end{array}$ & $\begin{array}{l}1.50 \\
2.50\end{array}$ & $\begin{array}{l}3.572 \\
3.562\end{array}$ & $\begin{array}{l}0.385 \\
0.588\end{array}$ & $\begin{array}{l}1.729 \\
2.923\end{array}$ \\
\hline $\begin{array}{l}3.50 \\
5.00\end{array}$ & $\begin{array}{l}3.586 \\
3.600\end{array}$ & $\begin{array}{l}0.713 \\
0.917\end{array}$ & $\begin{array}{l}4.408 \\
6.584\end{array}$ & $\begin{array}{l}3.50 \\
5.00\end{array}$ & $\begin{array}{l}3.570 \\
3.583\end{array}$ & $\begin{array}{l}0.757 \\
0.984\end{array}$ & $\begin{array}{l}4.241 \\
6.325\end{array}$ \\
\hline $\begin{array}{l}6.20 \\
7.50\end{array}$ & $\begin{array}{l}3.610 \\
3.620\end{array}$ & $\begin{array}{l}1.061 \\
1.200\end{array}$ & $\begin{array}{c}8.400 \\
10.44\end{array}$ & $\begin{array}{l}6.20 \\
7.50\end{array}$ & $\begin{array}{l}3.595 \\
3.607\end{array}$ & $\begin{array}{l}1.136 \\
1.280\end{array}$ & $\begin{array}{c}8.109 \\
10.13\end{array}$ \\
\hline $\begin{array}{l}10.00 \\
12.50\end{array}$ & $\begin{array}{l}3.642 \\
3.654\end{array}$ & $\begin{array}{l}1.379 \\
1.567\end{array}$ & $\begin{array}{l}14.71 \\
18.95\end{array}$ & $\begin{array}{l}10.00 \\
12.50\end{array}$ & $\begin{array}{l}3.624 \\
3.644\end{array}$ & $\begin{array}{l}1.533 \\
1.678\end{array}$ & $\begin{array}{l}14.11 \\
18.52\end{array}$ \\
\hline $\begin{array}{l}15.00 \\
20.00\end{array}$ & $\begin{array}{l}3.667 \\
3.688\end{array}$ & $\begin{array}{l}1.686 \\
1.821\end{array}$ & $\begin{array}{l}23.47 \\
32.92\end{array}$ & $\begin{array}{l}15.00 \\
20.00\end{array}$ & $\begin{array}{l}3.658 \\
3.683\end{array}$ & $\begin{array}{l}1.808 \\
1.917\end{array}$ & $\begin{array}{l}22.99 \\
32.54\end{array}$ \\
\hline
\end{tabular}




$$
\mathrm{Sm}^{+3}
$$

$\begin{array}{llll}0.50 & 3.586 & 0.194 & 0.483 \\ 1.00 & 3.504 & 0.350 & 0.912\end{array}$

$\begin{array}{llll}1.50 & 3.478 & 0.493 & 1.359 \\ 2.50 & 3.472 & 0.748 & 2.344\end{array}$

$\begin{array}{llll}3.50 & 3.489 & 0.958 & 3.492 \\ 5.00 & 3.512 & 1.241 & 5.345\end{array}$

$\begin{array}{llll}6.20 & 3.532 & 1.426 & 6.991\end{array}$

$7.50 \quad 3.554 \quad 1.584 \quad 8.942$

$\begin{array}{llll}10.00 & 3.585 & 1.845 & 12.88 \\ 12.50 & 3.611 & 2.024 & 17.15\end{array}$

$\begin{array}{llll}15.00 & 3.629 & 2.278 & 21.13 \\ 20.00 & 3.662 & 2.306 & 30.99\end{array}$

$$
\mathrm{Gd}^{+3}
$$

$\begin{array}{llll}0.50 & 3.526 & 0.225 & 0.399 \\ 1.00 & 3.437 & 0.402 & 0.757\end{array}$

$\begin{array}{llll}1.50 & 3.412 & 0.561 & 1.143 \\ 2.50 & 3.414 & 0.839 & 2.030\end{array}$

$\begin{array}{llll}3.50 & 3.437 & 1.072 & 3.078 \\ 5.00 & 3.474 & 1.363 & 4.884\end{array}$

$\begin{array}{llll}6.20 & 3.503 & 1.547 & 6.528\end{array}$

$\begin{array}{llll}7.50 & 3.528 & 1.721 & 8.413\end{array}$

$\begin{array}{llll}10.00 & 3.571 & 1.950 & 12.47 \\ 12.50 & 3.599 & 2.144 & 16.68\end{array}$

$\begin{array}{llll}15.00 & 3.618 & 2.322 & 20.95 \\ 20.00 & 3.655 & 2.431 & 30.50\end{array}$ $\begin{array}{llll}0.50 & 3.539 & 0.218 & 0.416 \\ 1.00 & 3.458 & 0.386 & 0.803\end{array}$

$\begin{array}{llll}1.50 & 3.435 & 0.538 & 1.215 \\ 2.50 & 3.434 & 0.809 & 2.134\end{array}$

$\begin{array}{llll}3.50 & 3.454 & 1.036 & 3.207 \\ 5.00 & 3.485 & 1.328 & 5.013\end{array}$

$\begin{array}{llll}6.20 & 3.511 & 1.514 & 6.654 \\ 7.50 & 3.535 & 1.684 & 8.555\end{array}$

$\begin{array}{llll}10.00 & 3.576 & 1.914 & 12.61 \\ 12.50 & 3.601 & 2.123 & 16.76\end{array}$

$\begin{array}{llll}15.00 & 3.623 & 2.260 & 21.20 \\ 20.00 & 3.658 & 2.378 & 30.71\end{array}$

$$
\mathrm{Tb}^{+3}
$$

$\begin{array}{llll}0.50 & 3.474 & 0.250 & 0.334 \\ 1.00 & 3.383 & 0.441 & 0.649\end{array}$

$\begin{array}{llll}1.50 & 3.358 & 0.612 & 0.990 \\ 2.50 & 3.362 & 0.913 & 1.782\end{array}$

$\begin{array}{llll}3.50 & 3.392 & 1.162 & 2.758 \\ 5.00 & 3.440 & 1.465 & 4.502\end{array}$

$\begin{array}{llll}6.20 & 3.476 & 1.652 & 6.125 \\ 7.50 & 3.507 & 1.826 & 8.008\end{array}$

$\begin{array}{llll}10.00 & 3.553 & 2.082 & 11.95 \\ 12.50 & 3.584 & 2.288 & 16.11\end{array}$

$\begin{array}{llll}15.00 & 3.606 & 2.467 & 20.38 \\ 20.00 & 3.645 & 2.608 & 29.80\end{array}$ 


$$
\mathrm{Dy}^{+}+3
$$

$\begin{array}{llll}0.50 & 3.444 & 0.265 & 0.301 \\ 1.00 & 3.349 & 0.465 & 0.587\end{array}$

$\begin{array}{llll}1.50 & 3.319 & 0.647 & 0.890 \\ 2.50 & 3.326 & 0.961 & 1.626\end{array}$

$\begin{array}{llll}3.50 & 3.362 & 1.218 & 2.563 \\ 5.00 & 3.41 \% & 1.530 & 4.262\end{array}$

$\begin{array}{llll}6.20 & 3.454 & 1.735 & 5.813 \\ 7.50 & 3.488 & 1.917 & 7.658\end{array}$

$\begin{array}{llll}10.00 & 3.540 & 2.173 & 11.60 \\ 12.50 & 3.575 & 2.374 & 15.77\end{array}$

$\begin{array}{llll}15.00 & 3.601 & 2.527 & 20.14\end{array}$

$$
\mathrm{Er}^{+3}
$$

$\begin{array}{llll}0.50 & 3.408 & 0.282 & 0.263 \\ 1.00 & 3.308 & 0.493 & 0.519\end{array}$

$\begin{array}{llll}1.50 & 3.278 & 0.683 & 0.795 \\ 2.50 & 3.288 & 1.010 & 1.476\end{array}$

$\begin{array}{llll}3.50 & 3.288 & 1.345 & 2.134 \\ 5.00 & 3.392 & 1.598 & 1.011\end{array}$

$6.20 \quad 3.431 \quad 1.818 \quad 5.055$

$\begin{array}{llll}7.50 & 3.474 & 1.981 & 7.411\end{array}$

$\begin{array}{llll}10.00 & 3.529 & 2.21 .8 & 11.30 \\ 12.50 & 3.567 & 2.447 & 15.48\end{array}$

$\begin{array}{llll}15.00 & 3.592 & 2.634 & 19.72\end{array}$

$\begin{array}{llll}15.00 & 3.635 & 2.777 & 20.12\end{array}$ $\begin{array}{llll}0.50 & 3.428 & 0.272 & 0.284\end{array}$

$\begin{array}{llll}1.00 & 3.333 & 0.476 & 0.560\end{array}$

$\begin{array}{llll}1.50 & 3.306 & 0.659 & 0.859 \\ 2.50 & 3.315 & 0.976 & 1.581\end{array}$

$\begin{array}{llll}3.50 & 3.354 & 1.232 & 2.513 \\ 5.00 & 3.409 & 1.552 & 4.181\end{array}$

$\begin{array}{llll}6.20 & 3.451 & 1.745 & 5.773 \\ 7.50 & 3.487 & 1.921 & 7.641\end{array}$

$\begin{array}{llll}10.00 & 3.539 & 2.180 & 11.57\end{array}$

$\begin{array}{llll}12.50 & 3.576 & 2.365 & 15.81\end{array}$

$\begin{array}{llll}15.00 & 3.602 & 2.515 & 20.19 \\ 20.00 & 3.643 & 2.641 & 29.66\end{array}$

$$
\mathrm{Tm}^{+3}
$$

$\begin{array}{llll}0.50 & 3.394 & 0.289 & 0.249 \\ 1.00 & 3.290 & 0.506 & 0.491\end{array}$

$\begin{array}{llll}1.50 & 3.260 & 0.699 & 0.755\end{array}$

$\begin{array}{llll}1.50 & 3.270 & 1.032 & 1.409\end{array}$

$\begin{array}{llll}3.50 & 3.311 & 1.307 & 2.260 \\ 5.00 & 3.377 & 1.637 & 3.871\end{array}$

$\begin{array}{llll}6.20 & 3.424 & 1.841 & 5.415\end{array}$

$\begin{array}{llll}7.50 & 3.465 & 2.022 & 7.254\end{array}$

$\begin{array}{llll}10.00 & 3.524 & 2.282 & 11.17 \\ 12.50 & 3.563 & 2.484 & 15.34\end{array}$

$\begin{array}{llll}15.00 & 3.591 & 2.643 & 19.68 \\ 20.00 & 3.635 & 2.777 & 29.12\end{array}$ 


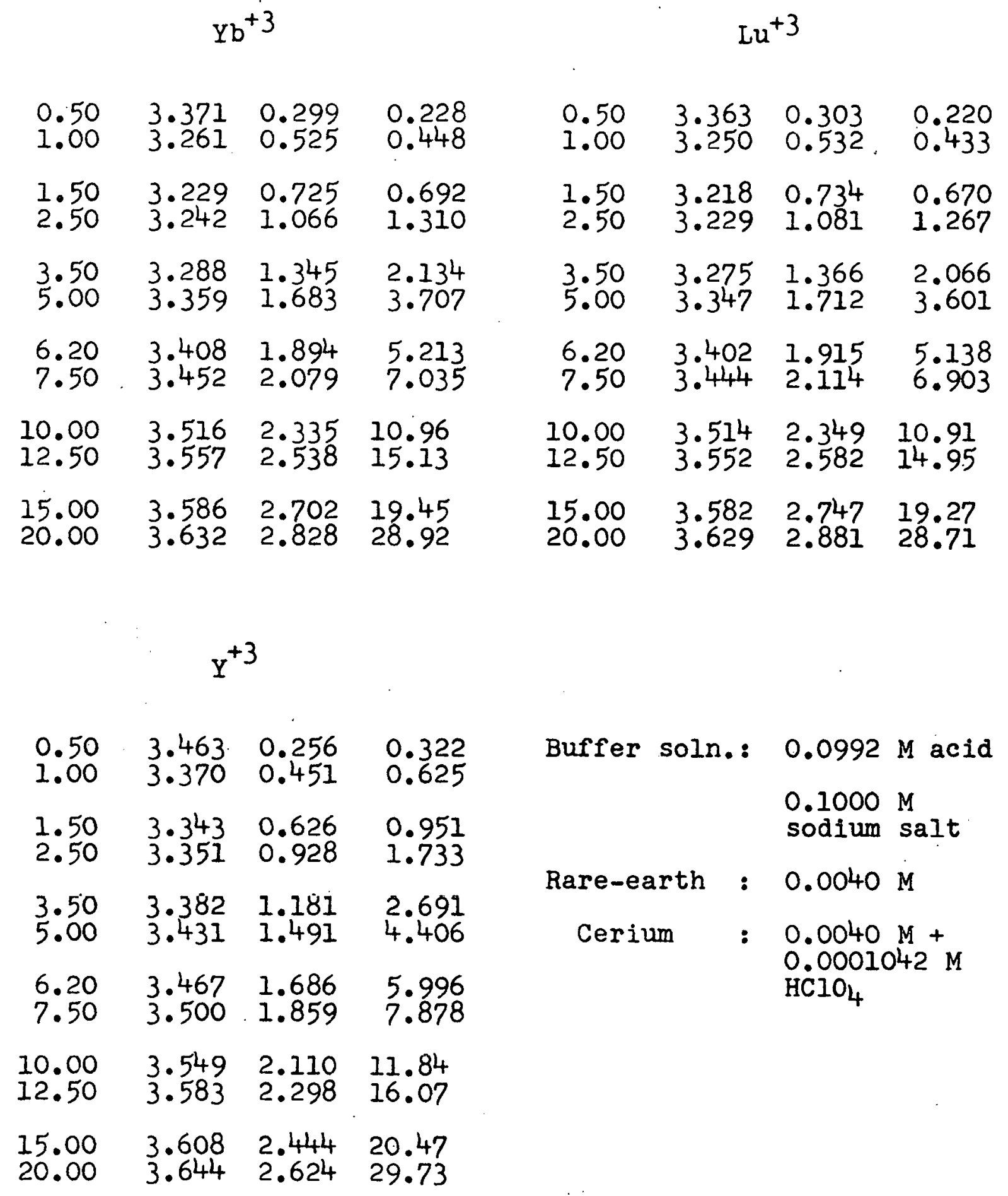


X. APPENDIX D: EXPERIMENTAL DATA FOR THE RARE-EARTH TERTIARYBUTYLGLYCOLATES

ml. $\mathrm{pH} \quad \overline{\mathrm{n}} \quad \mathrm{aXI0^{-3 }}$ $\frac{\text { buffer }}{50 \mathrm{ml}}$

soln.

$\begin{array}{llll}0.50 & 3.847 & 0.086 & 0.797 \\ 1.00 & 3.800 & 0.155 & 1.537\end{array}$

$\begin{array}{llll}1.50 & 3.784 & 0.221 & 2.282 \\ 2.50 & 3.775 & 0.340 & 3.809\end{array}$

$\begin{array}{llll}3.50 & 3.778 & 0.435 & 5.425\end{array}$

$\begin{array}{llll}5.00 & 3.784 & 0.561 & 7.919\end{array}$

$\begin{array}{llll}6.20 & 3.790 & 0.644 & 9.987\end{array}$

$\begin{array}{llll}7.50 & 3.795 & 0.726 & 12.25\end{array}$

$10.00 \cdot 3.812 \quad 0.779 \quad 17.04$

$\begin{array}{llll}12.50 & 3.818 & 0.881 & 21.63\end{array}$

$\begin{array}{llll}15.00 & 3.828 & 0.889 & 26.59\end{array}$

$$
\mathrm{Fr}^{+3}
$$

$\begin{array}{llll}0.50 & 3.790 & 0.120 & 0.682 \\ 1.00 & 3.737 & 0.218 & 1.311\end{array}$

$\begin{array}{llll}1.50 & 3.722 & 0.307 & 1.960\end{array}$

$\begin{array}{llll}2.50 & 3.716 & 0.471 & 3.308\end{array}$

$\begin{array}{llll}3.50 & 3.722 & 0.610 & 4.751\end{array}$

$\begin{array}{llll}6.20 & 3.735 & 0.950 & 8.783\end{array}$

$\begin{array}{llll}7.50 & 3.748 & 1.050 & 19.98\end{array}$

$\begin{array}{llll}10.00 & 3.765 & 1.223 & 15.28\end{array}$

$\begin{array}{llll}12.50 & 3.780 & 1.340 & 19.80\end{array}$

$\begin{array}{llll}15.00 & 3.793 & 1.410 & 24.52\end{array}$

$20.00 \quad 3.812 \quad 1.486 \quad 34.21$

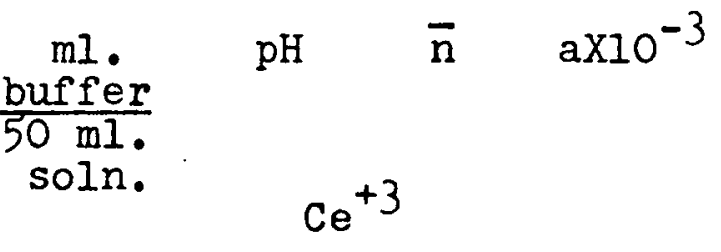

$\begin{array}{llll}0.50 & 3.745 & 0.099 & 0.689 \\ 1.00 & 3.725 & 0.185 & 1.346\end{array}$

$\begin{array}{llll}1.50 & 3.716 & 0.271 & 2.004\end{array}$

$\begin{array}{llll}1.50 & 3.714 & 0.431 & 3.365\end{array}$

$\begin{array}{llll}3.50 & 3.721 & 0.568 & 4.814 \\ 5.00 & 3.731 & 0.754 & 7.067\end{array}$

$\begin{array}{llll}6.20 & 3.7^{4}+2 & 0.867 & 9.008\end{array}$

$\begin{array}{llll}7.50 & 3.749 & 0.996 & 11.09\end{array}$

$\begin{array}{llll}10.00 & 3.764 & 1.186 & 15.32\end{array}$

$\begin{array}{llll}12.50 & 3.775 & 1.350 & 19.66\end{array}$

$\begin{array}{llll}15.00 & 3.786 & 1.467 & 24.21 \\ 20.00 & 3.805 & 1.576 & 33.75\end{array}$

$$
\mathrm{Nd}^{+3}
$$

$\begin{array}{llll}0.50 & 3.778 & 0.127 & 0.660 \\ 1.00 & 3.224 & 0.230 & 1.268\end{array}$

$\begin{array}{llll}1.50 & 3.706 & 0.328 & 1.884\end{array}$

$\begin{array}{llll}2.50 & 3.700 & 0.504 & 3.184\end{array}$

$\begin{array}{llll}3.50 & 3.705 & 0.658 & 4.566 \\ 5.00 & 3.719 & 0.848 & 6.798\end{array}$

$\begin{array}{rrrr}6.20 & 3.724 & 1.007 & 8.561 \\ 7.50 & 3.732 & 1.152 & 10.58\end{array}$

$\begin{array}{llll}10.00 & 3.752 & 1.338 & 14.83\end{array}$

$\begin{array}{llll}12.50 & 3.764 & 1.521 & 19.09\end{array}$

$\begin{array}{llll}15.00 & 3.775 & 1.662 & 23.52\end{array}$

$\begin{array}{llll}15.00 & 3.798 & 1.751 & 33.13\end{array}$ 


$$
\mathrm{Sm}^{+3}
$$

$\begin{array}{llll}0.50 & 3.720 & 0.157 & 0.561 \\ 1.00 & 3.662 & 0.284 & 1.082\end{array}$

$\begin{array}{llll}1.50 & 3.639 & 0.408 & 1.596 \\ 2.50 & 3.642 & 0.615 & 2.769\end{array}$

$\begin{array}{llll}3.50 & 3.652 & 0.799 & 4.026 \\ 5.00 & 3.671 & 1.035 & 6.073\end{array}$

$\begin{array}{llll}6.20 & 3.687 & 1.189 & 7.851\end{array}$

$\begin{array}{llll}7.50 & 3.701 & 1.340 & 9.840\end{array}$

$\begin{array}{llll}10.00 & 3.732 & 1.509 & 14.15\end{array}$

$\begin{array}{llll}15.00 & 3.765 & 1.797 & 22.98 \\ 20.00 & 3.794 & 1.835 & 32.82\end{array}$

$\mathrm{Gd}^{+3}$

0.50

1.00

$\begin{array}{ll}3.689 & 0.173 \\ 3.627 & 0.312\end{array}$

0.513
0.988

$\begin{array}{llll}1.50 & 3.610 & 0.440 & 1.484\end{array}$

$\begin{array}{llll}1.50 & 3.610 & 0.671 & 2.562\end{array}$

$\begin{array}{llll}3.50 & 3.623 & 0.870 & 3.757 \\ 5.00 & 3.649 & 1.115 & 5.766\end{array}$

6.20

7.50

$3.666 \quad 1.286$

3.6831 .443

7.473

9.437

$\begin{array}{llll}10.00 & 3.716 & 1.639 & 13.64\end{array}$

$\begin{array}{llll}12.50 & 3.738 & 1.803 & 17.97\end{array}$

$\begin{array}{llll}15.00 & 3.751 & 1.981 & 22.25\end{array}$

$20.00 \quad 3.782 \quad 2.061 \quad 31.92$ $\begin{array}{llll}0.50 & 3.697 & 0.169 & 0.525\end{array}$

$\begin{array}{lllll}1.00 & 3.641 & 0.301 & 1.024\end{array}$

$\begin{array}{llll}1.50 & 3.625 & 0.424 & 1.541 \\ 2.50 & 3.622 & 0.650 & 2.638\end{array}$

$\begin{array}{llll}3.50 & 3.635 & 0.841 & 3.866 \\ 5.00 & 3.655 & 1.093 & 5.848\end{array}$

$\begin{array}{llll}6.20 & 3.670 & 1.267 & 7.544 \\ 7.50 & 3.686 & 1.426 & 9.502\end{array}$

$\begin{array}{llll}10.00 & 3.716 & 1.639 & 13.64\end{array}$

$\begin{array}{llll}12.50 & 3.737 & 1.813 & 17.93\end{array}$

$\begin{array}{llll}15.00 & 3.753 & 1.955 & 22.36 \\ 20.00 & 3.784 & 2.022 & 32.08\end{array}$ $\begin{array}{llll}0.50 & 3.652 & 0.191 & 0.460\end{array}$

$\begin{array}{llll}1.50 & 3.568 & 0.484 & 1.335 \\ 2.50 & 3.570 & 0.736 & 2.325\end{array}$

$\begin{array}{llll}3.50 & 3.593 & 0.940 & 3.496 \\ 5.00 & 3.620 & 1.214 & 5.385\end{array}$

$\begin{array}{llll}6.20 & 3.644 & 1.382 & 7.098\end{array}$

$\begin{array}{llll}7.50 & 3.664 & 1.548 & 9.026\end{array}$

$\begin{array}{llll}10.00 & 3.701 & 1.759 & 13.17\end{array}$

$\begin{array}{llll}12.50 & 3.727 & 1.917 & .17 .52\end{array}$

$\begin{array}{llll}15.00 & 3.746 & 2.047 & 21.99 \\ 20.00 & 3.782 & 2.061 & 31.92\end{array}$ 


$$
\mathrm{Dy}^{+3}
$$

$\begin{array}{llllllll}0.50 & 3.628 & 0.202 & 0.428 & 0.50 & 3.614 & 0.208 & 0.410 \\ 1.00 & 3.564 & 0.359 & 0.836 & 1.00 & 3.550 & 0.369 & 0.806 \\ 1.50 & 3.548 & 0.504 & 1.269 & 1.50 & 3.534 & 0.517 & 1.224 \\ 2.50 & 3.554 & 0.761 & 2.236 & 2.50 & 3.540 & 0.782 & 2.161 \\ 3.50 & 3.573 & 0.984 & 3.333 & 3.50 & 3.562 & 1.007 & 3.246 \\ 5.00 & 3.608 & 1.253 & 5.235 & 5.00 & 3.596 & 1.292 & 5.087 \\ 6.20 & 3.628 & 1.450 & 6.837 & 6.20 & 3.624 & 1.466 & 6.772 \\ 7.50 & 3.649 & 1.627 & 8.716 & 7.50 & 3.651 & 1.617 & 8.755 \\ 10.00 & 3.688 & 1.857 & 12.78 & 10.00 & 3.690 & 1.843 & 12.83 \\ 12.50 & 3.717 & 2.020 & 17.11 & 12.50 & 3.717 & 2.020 & 17.11 \\ 15.00 & 3.737 & 2.159 & 21.55 & 15.00 & 3.739 & 2.135 & 21.64 \\ 20.00 & 3.771 & 2.261 & 31.13 & 20.00 & 3.773 & 2.228 & 31.26\end{array}$

\begin{tabular}{llllllll}
\multicolumn{1}{c}{$\operatorname{Er}^{+3}$} & \multicolumn{7}{c}{$\mathrm{Tm}^{+3}$} \\
0.50 & 3.607 & 0.211 & 0.402 & 0.50 & 3.586 & 0.221 & 0.376 \\
1.00 & 3.536 & 0.379 & 0.776 & 1.00 & 3.511 & 0.396 & 0.725 \\
1.50 & 3.520 & 0.530 & 1.181 & 1.50 & 3.491 & 0.557 & 1.096 \\
2.50 & 3.527 & 0.801 & 2.093 & 2.50 & 3.499 & 0.841 & 1.954 \\
3.50 & 3.550 & 1.032 & 3.155 & 3.50 & 3.525 & 1.082 & 2.971 \\
5.00 & 3.589 & 1.313 & 5.005 & 5.00 & 3.567 & 1.380 & 4.751 \\
6.20 & 3.611 & 1.519 & 6.569 & 6.20 & 3.502 & 1.554 & 6.433 \\
7.50 & 3.636 & 1.694 & $8.4+55$ & 7.50 & 3.529 & 1.730 & 8.317 \\
10.00 & 3.683 & 1.395 & 12.63 & 10.00 & 3.675 & 1.355 & 12.39 \\
12.50 & 3.710 & 2.089 & 16.84 & 12.50 & 3.704 & 2.148 & 16.61 \\
15.00 & 3.732 & 2.224 & 21.29 & 15.00 & 3.728 & 2.273 & 21.09 \\
20.00 & 3.770 & 2.279 & 31.05 & 20.00 & 3.764 & 2.388 & 30.62
\end{tabular}


$Y b^{+3}$

$\begin{array}{llll}0.50 & 3.564 & 0.230 & 0.351\end{array}$

$\begin{array}{llll}1.50 & 3.469 & 0.576 & 1.036 \\ 2.50 & 3.478 & 0.369 & 1.856\end{array}$

$\begin{array}{llll}3.50 & 3.508 & 1.115 & 2.851 \\ 5.00 & 3.553 & 1.421 & 4.596\end{array}$

$\begin{array}{llll}6.20 & 3.592 & 1.594 & 6.281\end{array}$

$\begin{array}{llll}7.50 & 3.621 & 1.769 & 8.165\end{array}$

$\begin{array}{llll}10.00 & 3.670 & 1.991 & 12.25 \\ 12.50 & 3.701 & 2.177 & 16.49\end{array}$

$\begin{array}{llll}15.00 & 3.725 & 2.310 & 20.95\end{array}$

$\begin{array}{llll}20.00 & 3.764 & 2.388 & 20.62\end{array}$ $\begin{array}{llll}0.50 & 3.558 & 0.233 & 0.345 \\ 1.00 & 3.482 & 0.415 & 0.669\end{array}$

$\begin{array}{llll}1.50 & 3.1+63 & 0.581 & 1.019 \\ 2.50 & 3.473 & 0.876 & 1.833\end{array}$

$\begin{array}{llll}3.50 & 3.502 & 1.126 & 2.810 \\ 5.00 & 3.550 & 1.429 & 4.564\end{array}$

$\begin{array}{llll}6.20 & 3.587 & 1.512 & 6.209 \\ 7.50 & 3.618 & 1.784 & 8.106\end{array}$

$\begin{array}{llll}10.00 & 3.665 & 2.027 & 12.11 \\ 12.50 & 3.698 & 2.205 & 16.38\end{array}$

$\begin{array}{llll}15.00 & 3.725 & 2.310 & 20.95\end{array}$

$$
Y^{+3}
$$

$\begin{array}{llll}0.50 & 3.656 & 0.189 & 0.466\end{array}$

$\begin{array}{llll}1.00 & 3.590 & 0.340 & 0.896\end{array}$

$\begin{array}{llll}1.50 & 3.570 & 0.482 & 1.341 \\ 2.50 & 3.573 & 0.731 & 2.342\end{array}$

$\begin{array}{llll}3.50 & 3.593 & 0.940 & 3.496 \\ 5.00 & 3.622 & 1.207 & 5.410\end{array}$

$\begin{array}{llll}6.20 & 3.644 & 1.382 & 7.098\end{array}$

$7.50 \quad 3.568 \quad 1.526 \quad 9.111$

$\begin{array}{llll}10.00 & 3.702 & 1.750 & 13.20\end{array}$

$\begin{array}{llll}12.50 & 3.725 & 1.939 & 17.43\end{array}$

$\begin{array}{llll}15.00 & 3.743 & 2.084 & 21.85 \\ 20.00 & 3.778 & 2.133 & 31.63\end{array}$
Buffer soln.: $0.0988 \mathrm{M}$ acld

$0.1000 \mathrm{M}$ sodium salt

Rare-earth : $0.0040 \mathrm{M}$

Cerium
$0.0040 \mathrm{M}+$ $0.0001042 \mathrm{M}$ $\mathrm{HClO}_{4}$ 
XI. APFENDIX E: EXPERIMENTAL DATA FOR THE RARE-EARTH NETHYLTERTIARYBUTYLGLYCOLATES

\begin{tabular}{|c|c|c|c|c|c|c|c|}
\hline$\frac{\begin{array}{c}\mathrm{ml} . \\
\text { buffer }\end{array}}{\text { soln. }}$ & $\mathrm{La}$ & +3 & $\operatorname{ax} 10^{-3}$ & $\begin{array}{c}\begin{array}{c}\mathrm{ml} . \\
\text { buffer }\end{array} \\
50 \mathrm{moln} \\
\text { soln. }\end{array}$ & $\mathrm{Ce}$ & $\bar{n}$ & $2 \times 10^{-3}$ \\
\hline $\begin{array}{l}1.00 \\
1.50\end{array}$ & $\begin{array}{l}4.199 \\
4.180\end{array}$ & $\begin{array}{l}0.109 \\
0.152\end{array}$ & $\begin{array}{l}0.845 \\
1.263\end{array}$ & $\begin{array}{l}1.00 \\
1.50\end{array}$ & $\begin{array}{l}4.139 \\
4.136\end{array}$ & $\begin{array}{l}0.109 \\
0.155\end{array}$ & $\begin{array}{l}0.803 \\
1.212\end{array}$ \\
\hline $\begin{array}{l}2.00 \\
2.50\end{array}$ & $\begin{array}{l}4.169 \\
4.163\end{array}$ & $\begin{array}{l}0.196 \\
0.238\end{array}$ & $\begin{array}{l}1.676 \\
2.093\end{array}$ & $\begin{array}{l}2.00 \\
2.50\end{array}$ & $\begin{array}{l}4.132 \\
4.129\end{array}$ & $\begin{array}{l}0.206 \\
0.258\end{array}$ & $\begin{array}{l}1.610 \\
2.007\end{array}$ \\
\hline $\begin{array}{l}3.50 \\
4.50\end{array}$ & $\begin{array}{l}4.164 \\
4.154\end{array}$ & $\begin{array}{l}0.329 \\
0.397\end{array}$ & $\begin{array}{l}2.912 \\
3.776\end{array}$ & $\begin{array}{l}3.50 \\
4.50\end{array}$ & $\begin{array}{l}4.129 \\
4.128\end{array}$ & $\begin{array}{l}0.350 \\
0.446\end{array}$ & $\begin{array}{l}2.823 \\
3.631\end{array}$ \\
\hline $\begin{array}{l}5.50 \\
6.50\end{array}$ & $\begin{array}{l}4.154 \\
4.154\end{array}$ & $\begin{array}{l}0.465 \\
0.532\end{array}$ & $\begin{array}{l}4.641 \\
5.506\end{array}$ & $\begin{array}{l}5.50 \\
6.50\end{array}$ & $\begin{array}{l}4.132 \\
4.133\end{array}$ & $\begin{array}{l}0.517 \\
0.500\end{array}$ & $\begin{array}{l}4.487 \\
5.321\end{array}$ \\
\hline $\begin{array}{r}7.50 \\
10.00\end{array}$ & $\begin{array}{l}4.154 \\
4.156\end{array}$ & $\begin{array}{l}0.600 \\
0.749\end{array}$ & $\begin{array}{l}6.370 \\
8.572\end{array}$ & $\begin{array}{r}7.50 \\
10.00\end{array}$ & $\begin{array}{l}4.134 \\
4.141\end{array}$ & $\begin{array}{l}0.581 \\
0.831\end{array}$ & $\begin{array}{l}6.160 \\
8.359\end{array}$ \\
\hline $\begin{array}{l}12.50 \\
15.00\end{array}$ & $\begin{array}{l}4.160 \\
4.164\end{array}$ & $\begin{array}{l}0.862 \\
0.956\end{array}$ & $\begin{array}{l}10.84 \\
13.16\end{array}$ & $\begin{array}{l}12.50 \\
15.00\end{array}$ & $\begin{array}{l}4.146 \\
4.154\end{array}$ & $\begin{array}{l}0.970 \\
1.040\end{array}$ & $\begin{array}{l}10.58 \\
12.94\end{array}$ \\
\hline 20.00 & 4.175 & 1.015 & 18.04 & 20.00 & 4.165 & 1.154 & 17.71 \\
\hline \multicolumn{4}{|c|}{$\mathrm{Pr}^{+3}$} & \multicolumn{4}{|c|}{$\mathrm{Nd}^{+3}$} \\
\hline $\begin{array}{l}1.00 \\
1.50\end{array}$ & $\begin{array}{l}4.159 \\
4.140\end{array}$ & $\begin{array}{l}0.154 \\
0.215\end{array}$ & $\begin{array}{l}0.761 \\
1.142\end{array}$ & $\begin{array}{l}1.00 \\
1.50\end{array}$ & $\begin{array}{l}4.145 \\
4.124\end{array}$ & $\begin{array}{l}0.169 \\
0.239\end{array}$ & $\begin{array}{l}0.733 \\
1.096\end{array}$ \\
\hline $\begin{array}{l}2.00 \\
2.50\end{array}$ & $\begin{array}{l}4.133 \\
4.131\end{array}$ & $\begin{array}{l}0.270 \\
0.379\end{array}$ & $\begin{array}{l}1.534 \\
1.936\end{array}$ & $\begin{array}{l}2.00 \\
2.50\end{array}$ & $\begin{array}{l}4.112 \\
4.108\end{array}$ & $\begin{array}{l}0.311 \\
0.374\end{array}$ & $\begin{array}{l}1.456 \\
1.030\end{array}$ \\
\hline $\begin{array}{l}3.50 \\
4.50\end{array}$ & $\begin{array}{l}4.118 \\
4.118\end{array}$ & $\begin{array}{l}0.452 \\
0.555\end{array}$ & $\begin{array}{l}2.671 \\
3.467\end{array}$ & $\begin{array}{r}3.50 \\
4.50\end{array}$ & $\begin{array}{l}4.107 \\
4.102\end{array}$ & $\begin{array}{l}0.488 \\
0.521\end{array}$ & $\begin{array}{l}2.502 \\
3.338\end{array}$ \\
\hline $\begin{array}{l}5.50 \\
6.50\end{array}$ & $\begin{array}{l}4.121 \\
4.124\end{array}$ & $\begin{array}{l}0.647 \\
0.740\end{array}$ & $\begin{array}{l}4.294 \\
5.095\end{array}$ & $\begin{array}{l}5.50 \\
6.50\end{array}$ & $\begin{array}{l}4.108 \\
4.111\end{array}$ & $\begin{array}{l}0.707 \\
0.801\end{array}$ & $\begin{array}{l}4.164 \\
4.876\end{array}$ \\
\hline $\begin{array}{r}7.50 \\
10.00\end{array}$ & $\begin{array}{l}4.124 \\
4.129\end{array}$ & $\begin{array}{l}0.819 \\
1.013\end{array}$ & $\begin{array}{l}5.938 \\
8.049\end{array}$ & $\begin{array}{r}7.50 \\
10.00\end{array}$ & $\begin{array}{l}4.117 \\
4.120\end{array}$ & $\begin{array}{l}0.868 \\
1.098\end{array}$ & $\begin{array}{l}5.841 \\
7.881\end{array}$ \\
\hline $\begin{array}{l}12.50 \\
15.50\end{array}$ & $\begin{array}{l}4.138 \\
4.146\end{array}$ & $\begin{array}{l}1.135 \\
1.227\end{array}$ & $\begin{array}{l}10.30 \\
12.32\end{array}$ & $\begin{array}{l}12.50 \\
15.50\end{array}$ & $\begin{array}{l}4.126 \\
4.138\end{array}$ & $\begin{array}{l}1.278 \\
1.344\end{array}$ & $\begin{array}{l}10.02 \\
12.39\end{array}$ \\
\hline 20.00 & 4.158 & 1.365 & 17.34 & $\begin{array}{l}20.00 \\
30.00\end{array}$ & $\begin{array}{l}4.154 \\
4.172\end{array}$ & $\begin{array}{l}1.487 \\
1.573\end{array}$ & $\begin{array}{l}17.18 \\
26.92\end{array}$ \\
\hline
\end{tabular}




$$
\mathrm{Sm}^{+3}
$$

$\begin{array}{llll}1.00 & 4.067 & 0.246 & 0.594\end{array}$

$\begin{array}{llll}1.50 & 4.044 & 0.349 & 0.893\end{array}$

$\begin{array}{llll}2.00 & 4.032 & 0.451 & 1.192\end{array}$

$\begin{array}{llll}2.50 & 4.038 & 0.535 & 1.522\end{array}$

$\begin{array}{llll}3.50 & 4.036 & 0.700 & 2.192 \\ 4.50 & 4.042 & 0.849 & 2.892\end{array}$

$\begin{array}{llll}5.50 & 4.054 & 0.963 & 3.663 \\ 6.50 & 4.061 & 1.082 & 4.422\end{array}$

$\begin{array}{llll}7.50 & 4.069 & 1.184 & 5.218\end{array}$

$\begin{array}{llll}10.00 & 4.087 & 1.393 & 7.296\end{array}$

$\begin{array}{llll}12.50 & 4.099 & 1.586 & 9.407\end{array}$

$\begin{array}{llll}15.00 & 4.114 & 1.681 & 11.71\end{array}$

$\begin{array}{llll}20.00 & 4.134 & 1.837 & 16.40\end{array}$

$\begin{array}{llll}30.00 & 4.163 & 1.851 & 26.37\end{array}$

$\mathrm{Gd}^{+3}$

$\begin{array}{llll}1.00 & 4.017 & 0.290 & 0.517\end{array}$

$\begin{array}{llll}1.50 & 3.995 & 0.408 & 0.785\end{array}$

$\begin{array}{llll}2.00 & 3.985 & 0.523 & 1.058 \\ 2.50 & 3.985 & 0.626 & 1.351\end{array}$

$\begin{array}{llll}3.50 & 3.995 & 0.809 & 1.984\end{array}$

$\begin{array}{llll}4.50 & 4.007 & 0.969 & 2.660\end{array}$

$\begin{array}{llll}5.50 & 4.021 & 1.104 & 3.387\end{array}$

$\begin{array}{llll}6.50 & 4.032 & 1.232 & 4.129\end{array}$

$\begin{array}{rrrr}7.50 & 4.045 & 1.330 & 4.931 \\ 10.00 & 4.049 & 1.529 & 7.028\end{array}$

$\begin{array}{llll}12.50 & 4.086 & 1.728 & 9.127 \\ 15.00 & 4.104 & 1.817 & 11.44\end{array}$

$\begin{array}{lllll}20.00 & 4.132 & 1.875 & 16.32\end{array}$ $\begin{array}{llll}1.00 & 4.041 & 0.269 & 0.553 \\ 1.50 & 4.016 & 0.383 & 0.330\end{array}$

$\begin{array}{llll}2.00 & 4.008 & 0.488 & 1.121\end{array}$

$2.50 \quad 4.007 \cdot 0.586 \quad 1.427$

$\begin{array}{llll}3.50 & 4.014 & 0.759 & 2.078 \\ 4.50 & 4.024 & 0.912 & 2.770\end{array}$

$\begin{array}{llll}5.50 & 4.034 & 1.050 & 3.493 \\ 6.50 & 4.047 & 1.155 & 4.279\end{array}$

$\begin{array}{rrrr}7.50 & 4.052 & 1.288 & 5.013 \\ 10.00 & 4.078 & 1.470 & 7.144\end{array}$

$\begin{array}{llll}12.50 & 4.095 & 1.630 & 9.321\end{array}$ $\begin{array}{llll}15.00 & 4.114 & 1.681 & 11.71\end{array}$

$\begin{array}{llll}20.00 & 4.131 & 1.894 & 16.29 \\ 30.00 & 4.156 & 2.062 & 25.95\end{array}$

$$
\mathrm{Tb}^{+3}
$$

$\begin{array}{llll}1.00 & 3.964 & 0.332 & 0.444 \\ 1.50 & 3.944 & 0.464 & 0.685\end{array}$

$\begin{array}{llll}2.00 & 3.940 & 0.586 & 0.943 \\ 2.50 & 3.941 & 0.703 & 1.209\end{array}$

$\begin{array}{llll}3.50 & 3.957 & 0.901 & 1.809\end{array}$

$\begin{array}{llll}4.50 & 3.973 & 1.078 & 2.451\end{array}$

$\begin{array}{llll}5.50 & 3.996 & 1.205 & 3.192 \\ 6.50 & 4.007 & 1.353 & 3.892\end{array}$

$\begin{array}{llll}7.50 & 4.022 & 1.462 & 4.671\end{array}$ $\begin{array}{llll}10.00 & 4.050 & 1.699 & 6.690\end{array}$

$\begin{array}{llll}12.50 & 4.072 & 1.875 & 8.834 \\ 15.00 & 4.090 & 2.001 & 11.08\end{array}$ $20.00 \quad 4.127 \quad 2.062 \quad 25.95$ 


$$
\mathrm{Dy}^{+3}
$$

$\begin{array}{lll}1.00 & 3.945 & 0.347 \\ 1.50 & 3.924 & 0.485\end{array}$

$\begin{array}{llll}2.00 & 3.919 & 0.514 & 0.893 \\ 2.50 & 3.926 & 0.727 & 1.164\end{array}$

$\begin{array}{llll}3.50 & 3.944 & 0.931 & 1.751 \\ 4.50 & 3.963 & 1.108 & 2.392\end{array}$

$\begin{array}{llll}5.50 & 3.984 & 1.252 & 3.100\end{array}$

$\begin{array}{llll}6.50 & 1.001 & 1.301 & 3.837\end{array}$

$\begin{array}{llll}7.50 & 4.019 & 1.479 & 4.638\end{array}$

$10.00 \quad 4.052 \quad 1.683 \quad 6.722$

$\begin{array}{llll}12.50 & 4.077 & 1.823 & 8.938\end{array}$

15.00

20.00
0.420

11.21

$\begin{array}{lll}4.121 & 2.081 & 15.91\end{array}$

$$
\mathrm{Er}^{+3}
$$

$\begin{array}{llll}1.00 & 3.914 & 0.369 & 0.384\end{array}$

$\begin{array}{llll}1.50 & 3.894 & 0.514 & 0.599\end{array}$

$\begin{array}{llll}2.00 & 3.890 & 0.651 & 0.828\end{array}$

$\begin{array}{llll}2.50 & 3.897 & 0.773 & 1.082\end{array}$

$\begin{array}{llll}3.50 & 3.921 & 0.983 & 1.555 \\ 4.50 & 3.944 & 1.165 & 2.284\end{array}$

$\begin{array}{llll}5.50 & 3.972 & 1.297 & 3.012 \\ 6.50 & 3.990 & 1.431 & 3.739\end{array}$

$\begin{array}{lllll}7.50 & 4.008 & 1.540 & 1.519\end{array}$

$\begin{array}{llll}10.00 & 4.044 & 1.747 & 6.597\end{array}$

$\begin{array}{cccc}12.50 & 4.068 & 1.917 & 8.752 \\ 15.00 & 4.091 & 1.989 & 11.10\end{array}$

$\begin{array}{llll}20.00 & 4.119 & 2.118 & 15.84\end{array}$
$\mathrm{Ho}^{+3}$

$\begin{array}{llll}1.00 & 3.925 & 0.361 & 0.396 \\ 1.50 & 3.902 & 0.507 & 0.512\end{array}$

$\begin{array}{llll}2.00 & 3.902 & 0.636 & 0.854\end{array}$

$\begin{array}{llll}2.50 & 3.904 & 0.761 & 1.102\end{array}$

$\begin{array}{llll}3.50 & 3.927 & 0.969 & 1.680 \\ 4.50 & 3.950 & 1.147 & 2.318\end{array}$

$\begin{array}{llll}5.50 & 3.972 & 1.297 & 3.012 \\ 6.50 & 3.989 & 1.437 & 3.728\end{array}$

$\begin{array}{rrrr}7.50 & 4.007 & 1.545 & 4.509 \\ 10.00 & 4.043 & 1.754 & 6.582\end{array}$

$\begin{array}{llll}12.50 & 4.066 & 1.937 & 8.711\end{array}$

$\begin{array}{llll}15.00 & 4.086 & 2.054 & 10.97\end{array}$

$\begin{array}{llll}20.00 & 4.122 & 2.063 & 15.95 \\ 30.00 & 4.154 & 2.124 & 25.82\end{array}$ $\begin{array}{llll}1.00 & 3.896 & 0.382 & 0.363 \\ 1.50 & 3.874 & 0.534 & 0.566\end{array}$

$\begin{array}{llll}2.00 & 3.876 & 0.668 & 0.798\end{array}$

$\begin{array}{llll}2.50 & 3.883 & 0.793 & 1.044\end{array}$

$\begin{array}{llll}3.50 & 3.904 & 1.018 & 1.588 \\ 4.50 & 3.927 & 1.213 & 2.193\end{array}$

$\begin{array}{llll}5.50 & 3.957 & 1.351 & 2.907 \\ 6.50 & 3.978 & 1.486 & 3.633\end{array}$

$\begin{array}{rrrr}7.50 & 3.994 & 1.615 & 4.372 \\ 10.00 & 4.036 & 1.809 & 6.475\end{array}$

$\begin{array}{llll}12.50 & 4.061 & 1.989 & 8.510\end{array}$

$\begin{array}{llll}15.00 & 4.085 & 2.066 & 10.95\end{array}$

$20.00 \quad 4.116 \quad 2.174 \quad 15.73$ 


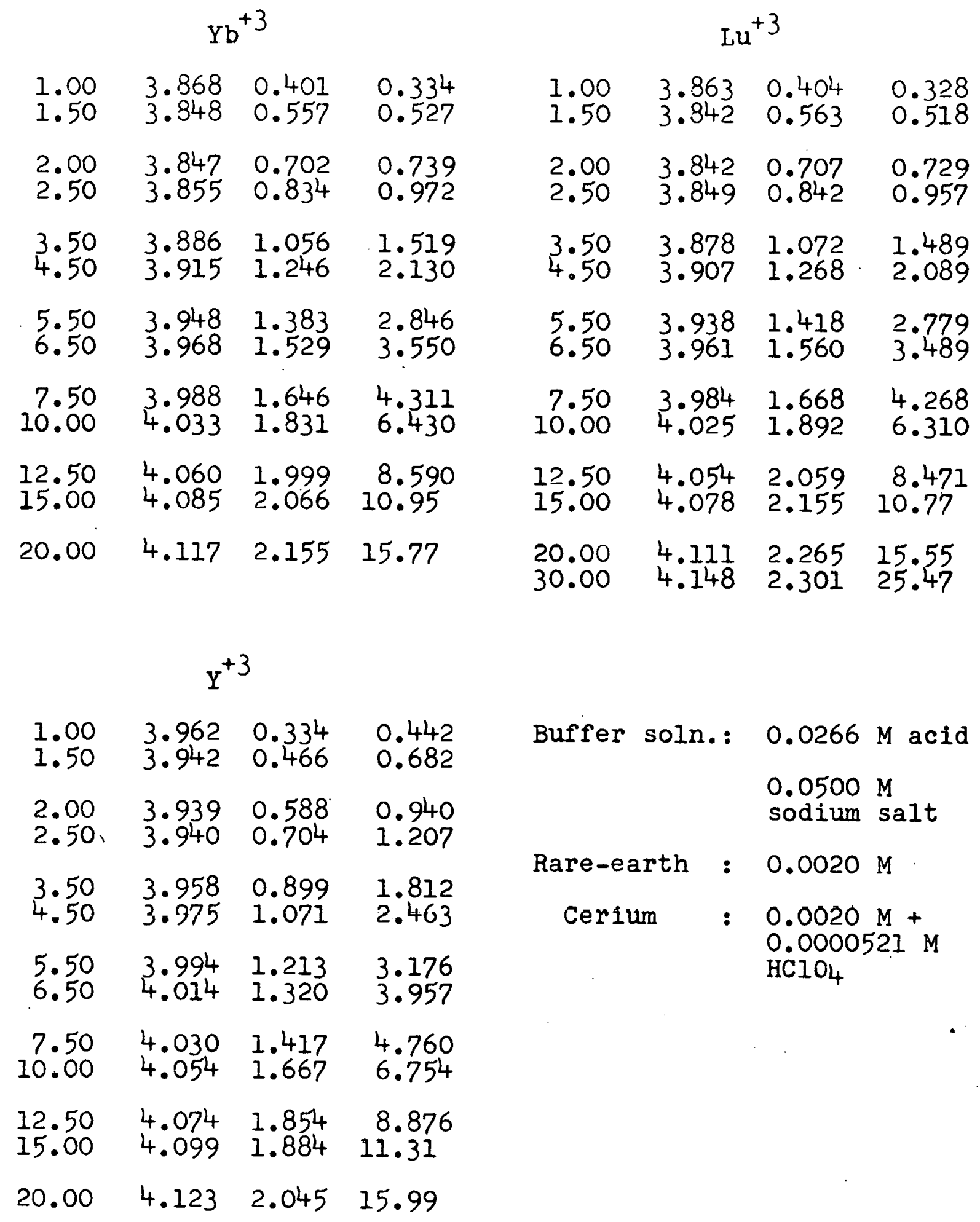

